\title{
Seasonal distribution of dissolved inorganic carbon and net community production on the Bering Sea shelf
}

\author{
J. T. Mathis ${ }^{1}$, J. N. Cross ${ }^{1}$, N. R. Bates ${ }^{2}$, S. Bradley Moran ${ }^{3}$, M. W. Lomas ${ }^{2}$, C. W. Mordy ${ }^{4}$, and P. J. Stabeno ${ }^{4}$ \\ ${ }^{1}$ University of Alaska Fairbanks, School of Fisheries and Ocean Sciences, 245 O’Neill BLDG, Fairbanks, AK 99775 USA \\ ${ }^{2}$ Bermuda Institute of Ocean Sciences, 17 Biological Lane, Ferry Reach, GE01, Bermuda \\ ${ }^{3}$ University of Rhode Island, 70 Lower College Rd., Kingston, RI 02881, USA \\ ${ }^{4}$ National Oceanic and Atmospheric Administration, Pacific Marine Environmental Lab, 7600 Sand Point Way NE, Seattle, \\ WA 98115, USA
}

Received: 18 December 2009 - Published in Biogeosciences Discuss.: 14 January 2010

Revised: 26 April 2010 - Accepted: 10 May 2010 - Published: 28 May 2010

\begin{abstract}
In order to assess the current state of net community production (NCP) in the southeastern Bering Sea, we measured the spatio-temporal distribution and controls on dissolved inorganic carbon (DIC) concentrations in spring and summer of 2008 across six shelf domains defined by differing biogeochemical characteristics. DIC concentrations were tightly coupled to salinity in spring and ranged from $\sim 1900 \mu$ moles kg ${ }^{-1}$ over the inner shelf to $\sim 2400 \mu$ moles $\mathrm{kg}^{-1}$ in the deeper waters of the Bering Sea. In summer, DIC concentrations were lower due to dilution from sea ice melt, terrestrial inputs, and primary production. Concentrations were found to be as low $\sim 1800 \mu$ moles $\mathrm{kg}^{-1}$ over the inner shelf. We found that DIC concentrations were drawn down $30-150 \mu$ moles $\mathrm{kg}^{-1}$ in the upper $30 \mathrm{~m}$ of the water column due to primary production and calcium carbonate formation between the spring and summer occupations. Using the seasonal drawdown of DIC, estimated rates of NCP on the inner, middle, and outer shelf averaged $28 \pm 9$ mmoles $\mathrm{C} \mathrm{m}^{-2} \mathrm{~d}^{-1}$. However, higher rates of NCP (4047 mmoles $\mathrm{C} \mathrm{m}^{-2} \mathrm{~d}^{-1}$ ) were observed in the "Green Belt" where the greatest confluence of nutrient-rich basin water and iron-rich shelf water occurs. We estimated that in 2008, total NCP across the shelf was on the order of $\sim 96 \mathrm{Tg} \mathrm{C} \mathrm{yr}^{-1}$. Due to the paucity of consistent, comparable productivity data, it is impossible at this time to quantify whether the system is becoming more or less productive. However, as changing climate continues to modify the character of the Bering Sea, we have shown that NCP can be an important indicator of how the ecosystem is functioning.
\end{abstract}

Correspondence to: J. T. Mathis

(jmathis@sfos.uaf.edu)

\section{Introduction}

The southeastern Bering Sea Shelf (Fig. 1) is one of the oceans' most productive ecosystems, home to over 450 species of fish, 50 species of seabirds, and 25 species of marine mammals (NRC, 1996). This expansive shelf area sustains almost half of the total US fish landings annually through massive Pollock (Theragra chalcogramma) and salmon populations, the majority of the US nesting seabird population, and some of the highest benthic faunal biomass in the world's ocean (Grebmeier and McRoy, 1981; Grebmeier et al., 2006).

Over the past several decades, the physical controls and biological character of the Bering Sea shelf ecosystem have undergone a shift, including notable increases in the dominance of temperate features coupled to the decline of arctic characteristics, changes in pelagic and benthic ecosystem structure, and decreases in the abundance of commercially important organisms (e.g., Grebmeier et al., 2006; Macklin et al., 2002; Stabeno et al., 1999; Overland and Stabeno, 2004; Hunt et al., 2002; Bond et al., 2003; Stockwell, et al., 2001). While most of these changes have been observed on the southeastern shelf, there is some evidence of change on the northern shelf as well (Overland and Stabeno, 2004; Grebmeier et al., 2006).

Recent ecosystem variability in the Bering Sea has been partly linked to global climate change and recent fluctuations in sea ice extent (e.g., Francis et al., 1998; Springer, 1998; Hollowed et al., 2001; Hunt et al., 2002; Rho and Whitledge, 2007). Due to amplification of the global warming signal in Arctic and Sub-arctic regions (Bryan and Spelman, 1985; Roots, 1989; Serreze and Francis, 2006; Turner et al., 2007), further changes to the physical forcing on the shelf will

Published by Copernicus Publications on behalf of the European Geosciences Union. 


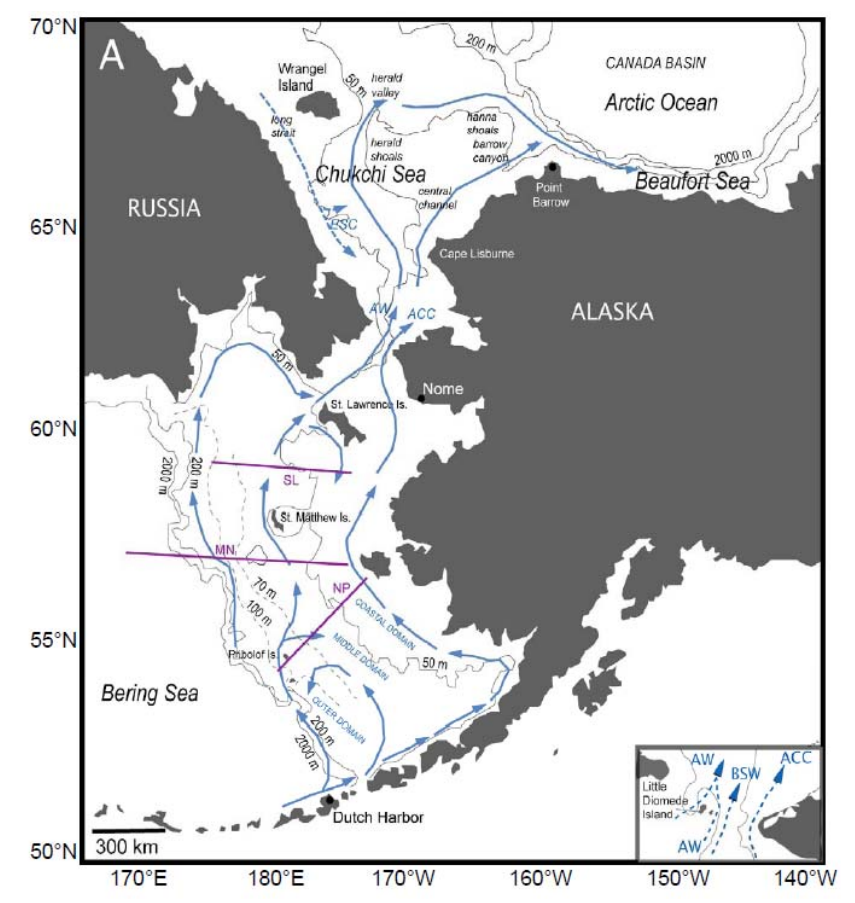

Fig. 1. Map of the Bering Sea showing the locations of the three domains, Outer Middle and Coastal. The locations of the three eastwest transect lines (SL, MN, and NP) are also shown as well as the generalize circulation. During the winter, sea-ice covers much of the Bering Sea shelf, but the advance is constrained by the presence of relatively warm water in the central and southern Bering Sea. During winter, water-masses are confined to a small range of temperature-salinity through mixing and homogenization by ventilation, brine rejection and mixing. During the summertime, sea-ice retreats into the Chukchi Sea and Canada Basin of the Arctic Ocean.

likely result in continued ecosystem change in the Bering Sea (Stabeno et al., 1999; Schumacher and Alexander, 1999; Hunt and Stabeno, 2002; Schumacher et al., 2002). Of particular concern is the possibility that the ecosystem may transition to an alternative state, which could be less economically viable for current fisheries (e.g., Hunt and Stabeno, 2002; Parsons, 1996; Scheffer et al., 2001; Kruse, 1998; Napp and Hunt, 2001).

In addition to impacting the distribution and abundance of higher trophic levels, climate change could be affecting pelagic phytoplankton net primary production (NPP) and food web dynamics (Hunt et al., 2002; Hunt and Stabeno, 2002). In order to assess the current state of NCP in the southeastern Bering Sea, we describe the spatiotemporal distribution and controls on dissolved inorganic carbon (DIC) concentrations across six domains defined by differing biogeochemical characteristics. We then use the seasonal drawdown of DIC in the mixed layer to estimate rates of net community production (NCP), which can be used as an indicator of ecosystem functionality (e.g. Bates et al., 2005, Mathis et al., 2009). Because a number of processes

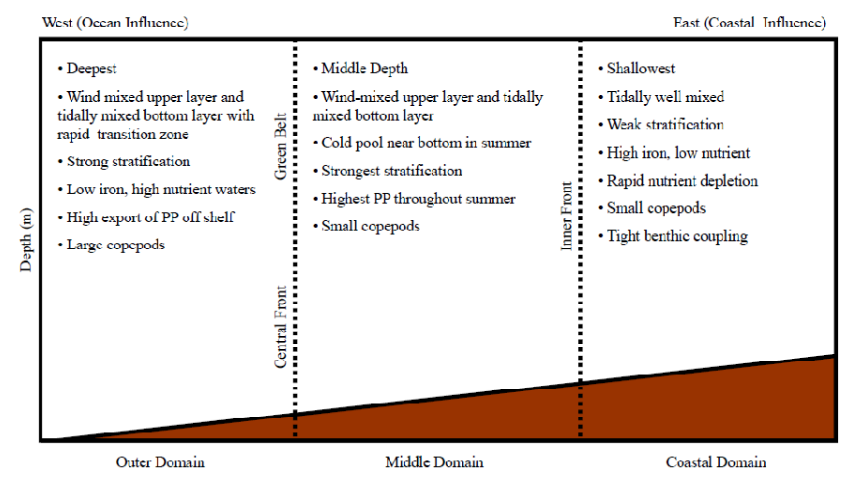

Fig. 2. Biogeochemical features of the Outer, Middle, and Coastal domains of the Bering Sea Shelf.

impact the cycling and fate of carbon in the ecosystem including the timing of sea ice retreat, water temperature, stratification, and species abundance (Hunt and Stabeno, 2002), NCP is a valuable tool in assessing net ecosystem production (NEP; Andersson et al., 2004).

\section{Background}

\subsection{Hydrography of the Bering Sea shelf}

\subsubsection{Geographic domains and frontal systems}

The $>500000 \mathrm{~km}^{2}$ of the Bering Sea shelf is split into roughly six domains (Fig. 1). The entire shelf can be divided into northern and southern regions at approximately $60^{\circ} \mathrm{N}$ based on the relative influence of sea ice on bottom water temperatures (e.g. Stabeno et al., 2002; Ohtani and Azumaya, 1995; Wyllie-Escheveria, 1995; Wyllie-Escheveria and Wooster, 1998; Coachman, 1986). Three along-shelf domains also exist, differentiated by frontal features imparted by strong horizontal property gradients during summer (e.g., Coachman, 1986; Kinder and Coachman, 1978; Coachman and Charnell, 1979; Stabeno et al., 2002; Kachel et al., 2002). The Inner Front, overlying the $50 \mathrm{~m}$ isobath (Kachel et al., 2002), divides the "Coastal Domain" from the "Middle Domain" (Figs. 1, 2). The "Central Front", a broad transitional zone between the $80 \mathrm{~m}$ and $100 \mathrm{~m}$ isobaths (Coachman, 1986), separates the middle and outer domains. The "Shelf-Break Front", between the $170 \mathrm{~m}$ and $250 \mathrm{~m}$ isobaths (Schumacher and Stabeno, 1998), divides the outer shelf from basin waters (Fig. 2). In summer, these fronts inhibit most cross-shelf advection and mixing (Stabeno and Hunt, 2002; Coachman, 1986; Kachel et al., 2002). 


\subsubsection{Hydrographic structure}

The annual formation and melting of sea-ice is one of the greatest contributors to water column structure in the Bering Sea. The $\sim 1700 \mathrm{~km}$ advance and retreat of sea ice over the Bering Sea Shelf is the largest in any of the Arctic or Subarctic regions (Walsh and Johnson, 1979), making it a significant source and sink for freshwater over the shelf. Increases in freshwater content caused by melting modify the water column density gradients, contributing to the maintenance of the summer stratification necessary for production (see Optimum Stability estimates by Coyle et al., 2008). Because sea-ice retreat begins in the south (Pease, 1980; Neibauer et al., 1990), ice persists longer over the northern shelf and northern bottom water temperatures in summer and fall are lower, leading to the division of the cross-shelf domains at $\sim 60^{\circ} \mathrm{N}$. Sea-ice persistence also plays a role in the formation of a cold water mass $\left(<2{ }^{\circ} \mathrm{C}\right.$; Maeda, 1977 ; Khen, 1998) isolated by thermal stratification in the Middle Domain (Stabeno et al, 2002; Wyllie-Escheveria, 1995; Wyllie-Escheveria and Wooster, 1998).

The other major contributor to hydrographic structure in this region is tidal mixing. As the dominant source of total kinetic energy flow across the shelf (Coachman, 1986; Stabeno et al., 2006), tidal forces typically mix the water column to about $40 \mathrm{~m}$, creating a well-mixed bottom layer in each domain. Because the Coastal Domain averages a depth of less than $50 \mathrm{~m}$, tidal energy and wind mixing completely overturn the water column and prevent the formation of strong stratification in summer. A well stratified, two-layer system characterizes the Middle (50-100 m) and Outer (100-180 m) Domains, where wind mixes the surface waters over a denser, tidally mixed bottom layer. In the deeper Outer Domain the wind-mixed surface layer and tidally-mixed bottom layer are separated by a sharp pycnocline (Stabeno et al., 2006). Summertime stratification is typically strongest in the Middle Domain and weakest in the Coastal Domain.

\subsubsection{Nutrients}

Inorganic nitrogen is widely considered to be the limiting nutrient to primary production over the Bering Sea shelf because surface layer concentrations are usually depleted to undetectable levels by late spring or early summer (Niebauer et al., 1995; Hattori and Goering, 1981; Whitledge et al., 1988; Whitledge and Luchin, 1999; Wong et al., 2002). Although cross-shelf advection and diffusion are largely prohibited by strong stratification and frontal systems, post-production inorganic nitrogen stocks can sometimes be minimally renewed by the interaction of deep basin water with Bering Shelf water to produce brief summer-time blooms. In addition, storms during the summer can mix nitrate from the bottom layer into the surface to support short-term blooms over the Middle and Outer Domains. Shelf-break topography, mesoscale eddies and summer storms can contribute small amounts of inorganic nitrogen as far as the Coastal Domain through shelf-slope exchange, but nutrient content and renewal is typically higher near the shelf break and slope due to proximity to basin waters (e.g., Mizobata and Saitoh, 2004; Stabeno et al., 1999; Whitledge and Luchin, 1999; Sambrotto et al., 1986; Schumacher and Reed, 1992; Stabeno and van Meurs, 1999; Schumacher and Stabeno, 1994 and 1998; Mizobata et al., 2002; Bond and Overland, 2005; Rho et al., 2005; Whitledge et al., 1986).

\subsection{Primary production in the Bering Sea}

Because of the importance of Bering Sea shelf fisheries, there have been numerous studies of pelagic primary production over the southeast shelf (Table 1). The first efforts in this region began in the early 1960s, using the abundance of fish supported by the ecosystem to infer the necessary amount of primary production $\left(900 \mathrm{mg} \mathrm{C} \mathrm{m}^{-2} \mathrm{~d}^{-1}\right.$; Graham and Edwards, 1962). By the 1970s, the most common method for measurement of primary production (PP) became the in situ ${ }^{14} \mathrm{C}$ technique developed by Sorokin (1960), which is still widely used today (e.g., Koblentz-Mishke et al., 1970; Motoda and Minoda, 1974; McRoy and Goering, 1976; Saino et al., 1979; Tsiban and Korsak, 1987; Sorokin, 1999; Rho and Whitledge, 2007). A comprehensive review of primary production in the Bering Sea was published by Springer et al., 1996 (updated here), which shows that production in the various domains across the shelf can be highly variable.

\subsubsection{Primary production variability within the different Bering Sea shelf domains}

Outer Domain. Although nitrate is present in sufficient concentrations to support significant productivity in the outer domain of the Bering Sea Shelf, production is low in this region compared to the middle shelf. This is likely due to iron limitation: in general, iron concentrations tend to be highest nearer the coast, and decrease off the shelf where iron-deficient basin waters have a greater influence on the water column (Fujishima et al., 2001; Takata el al., 2005; Suzuki et al., 2002; Sambrotto et al., 2008). Over the Outer Domain, iron is not present in high enough concentrations to allow complete drawdown of macronutrients, and some classify this area as a High-Nutrient, Low-Chlorophyll system as a result (Aguilar-Islas et al., 2007; Banse and English, 1999; Fung et al., 2000; Moore et al., 2002). Other work suggests that in iron-limited HNLC systems, particularly those dominated by basin waters, a secondary silicic acid limitation arises (Hutchins and Bruland, 1998; Koike et al., 2001). This silicate limitation may further restrict the accumulation of phytoplankton biomass in the outer domain.

Middle Domain. Macro- and micronutrient concentrations trend inversely to each other, and sufficiently high concentrations of each seem to coincide at approximately the central front where a highly productive region known as the 
Table 1. Select estimates of primary production in the Southeastern Bering Sea.

\begin{tabular}{|c|c|c|c|c|c|c|c|}
\hline \multirow[b]{2}{*}{ Investigator } & \multirow[b]{2}{*}{ Year } & \multirow[b]{2}{*}{ Method } & \multicolumn{5}{|c|}{ Production, $\mathrm{mmol} \mathrm{C} \mathrm{m}^{-2} \mathrm{~d}^{-1}$} \\
\hline & & & $\begin{array}{l}\text { Total } \\
\text { Bering } \\
\text { Sea }\end{array}$ & $\begin{array}{l}\text { Green } \\
\text { Belt }\end{array}$ & $\begin{array}{l}\text { Outer } \\
\text { Domain }\end{array}$ & $\begin{array}{l}\text { Middle } \\
\text { Domain }\end{array}$ & $\begin{array}{l}\text { Inner } \\
\text { Domain }\end{array}$ \\
\hline Graham and Edwards & 1962 & Stock of Fish Supported & 75 & & & & \\
\hline Koblentz-Mishke et al & 1970 & Radiocarbon incubations & $13-42$ & & & & \\
\hline Taguchi & 1972 & Radiocarbon incubations & 77 & & & & \\
\hline Motoda and Minoda & 1974 & Radiocarbon incubations & 42 & & & & \\
\hline McRoy and Goering & 1976 & Radiocarbon incubations & 67 & & & & \\
\hline Saino et al & 1979 & Radiocarbon incubations & $0-342$ & & & & \\
\hline Tsiban and Korsak & 1987 & Radiocarbon incubations & 53 & & & & \\
\hline Springer et al. & 1996 & Assimilation of Data & & 51 & 33 & 31 & 17 \\
\hline Sorokin & 1999 & Radiocarbon incubations & 117 & & & & \\
\hline Walsh and Dieterle & 1994 & Model & & & & 37 & \\
\hline Rho and Whitledge 2007 & $\begin{array}{l}1978-1981 \\
+1997-2000\end{array}$ & Radiocarbon Incubations & & & 33 & 34 & 28 \\
\hline
\end{tabular}

"Green Belt" spans parts of both the Middle and Outer Domains and the slope (Springer et al., 1996; Okkonen et al., 2004). Here, the confluence of coastally derived iron from weak cross-shelf flows, bioavailable sedimentary iron from Middle and Coastal Domain sediments mixed into the water column through tidal currents during winter, and basinderived nutrients from upwelled deep water supports a large accumulation of biomass in summer (Simpson and McRoy, 1999; McRoy et al., 2001). Unique fluid dynamics occurring at the Central Front may also trap phytoplankton in this idealized regime (Sorokin and Mikheev, 1979; Mackas et al., 1985; Coachman et al., 1986; Franks, 1992; Springer et al., 1996), contributing to the high primary production signal of the area. Annual PP rates here are further bolstered by the continuous supply of both nutrients and iron throughout the summer by eddies and mixing, which prolong the production season (e.g., Whitledge et al., 1986; Rho et al., 2005; Springer et al., 1996).

Coastal Domain. Frontal systems block the Coastal Domain from such extensive influence of high-nutrient basin water. Nutrient concentrations here are lower to begin the production season, and mechanisms of nutrient resupply are limited except along the Inner Front, where nutrients can be introduced from the nutrient rich bottom layer of the Middle Domain. In contrast to the Middle and Outer Domains, the shallow, coastally influenced waters of the Coastal Domain are iron-replete (Aguilar-Islas et al., 2007). Elevated iron concentrations permit high rates of production early in the season, but nutrient exhaustion in the euphotic zone typically prohibits extended periods of PP (e.g., Whitledge et al., 1986; Rho et al., 2005; Bond and Overland, 2005; Sambrotto and Goering, 1983; Sambrotto et al., 1986; Hansell et al., 1993; Springer and McRoy, 1993).

\subsubsection{Other physical and biogeochemical controls on PP}

Primary production in the Bering Sea tends to occur in two phases. Early in the season, the melting of sea-ice and decreased wind mixing force the water column to stratify in the marginal ice-edge zone. This fosters an intense bloom at the ice edge. However, following ice retreat, wind mixing is sometimes sufficient to break down the density stratification imparted by the fresh meltwater (e.g., Lovvorn et al., 2005; Niebauer et al., 1990, 1995) and limit continued open water PP. The second phase of PP occurs when solar radiation stabilizes the water column enough to support an open-water bloom. Both pulses in the production cycle are dependent on the timing of sea ice retreat. When sea-ice retreats early, light levels are insufficient for production, and the bloom is delayed. During this lag, solar radiation increases and heats the water column, providing ideal temperature conditions for zooplankton growth. By the time the bloom develops, zooplankton biomass is high and heavy grazing pressure likely reduces the amount of organic carbon exported to the benthos (Saitoh et al., 2002; Lovvorn et al., 2005). When ice retreat comes later in the season, stratification and solar radiation do not limit primary production. Additionally, colder water temperatures persist and limit zooplankton development. With minimal grazing pressure on the bloom, the amount of carbon export to the benthos increases. When sea-ice does not extend over a given area, solar radiation alone imparts stratification much later in the season and production is consequently grazed heavily by copepods, lending to a greater pelagic character. 
Table 2. Previous estimates of NCP in the Southeastern Bering Sea, calculated using the drawdown in oxygen, nitrogen, and inorganic carbon. Estimates based on oxygen consumption were converted to carbon based production values in the original work. Estimates of nitrate production were converted to carbon-based production within the original study or by using f-ratios of 0.4 for the middle and outer domains and 0.3 for the inner domain.

\begin{tabular}{|c|c|c|c|c|c|c|c|c|c|}
\hline \multirow[b]{2}{*}{ Investigator } & \multirow[b]{2}{*}{ Year } & \multirow[b]{2}{*}{ Timing } & \multirow[b]{2}{*}{ Method } & \multicolumn{6}{|c|}{ Production, $\mathrm{mmol} \mathrm{C}^{-2} \mathrm{~d}^{-1}$} \\
\hline & & & & $\begin{array}{l}\text { Total } \\
\text { Bering Sea }\end{array}$ & $\begin{array}{l}\text { Outer } \\
\text { Domain }\end{array}$ & $\begin{array}{l}\text { Middle } \\
\text { Domain }\end{array}$ & $\begin{array}{l}\text { Inner } \\
\text { Domain }\end{array}$ & $\begin{array}{l}\text { Northern } \\
\text { Domain }\end{array}$ & $\begin{array}{l}\text { Southern } \\
\text { Domain }\end{array}$ \\
\hline Ivanenkov & 1961 & Annual & Oxygen Modification & 217 & & & & & \\
\hline Azova & 1964 & Summer (July) & Oxygen Modification & & 667 & & & & \\
\hline $\begin{array}{l}\text { Sapozhnikov and } \\
\text { Naletova } 1995\end{array}$ & 1992 & Summer (June) & Oxygen Modification & 64 & & & & & \\
\hline Hansell et al & 1993 & $\begin{array}{l}\text { Summer } \\
\text { (midsummer) }\end{array}$ & New Nitrate Production & & $3-40$ & $17-29$ & $<16$ & 132 & \\
\hline Codispoti et al., 1982 & 1980 & Spring Bloom & DIC/NCP & & & $14-23$ & & & \\
\hline Codispoti, 1986 & 1980 & Spring Bloom & $\mathrm{DIC} / \mathrm{NCP}$ & & & & & & 200 \\
\hline Codispoti, 1986 & 1981 & Spring Bloom & $\mathrm{DIC} / \mathrm{NCP}$ & & & & & & 100 \\
\hline
\end{tabular}

\subsection{Net Community Production}

An alternative approach to direct-rate estimates of net primary production uses the seasonal consumption or production of the reaction products of photosynthesis (e.g. dissolved inorganic carbon, inorganic nitrogen, or dissolved oxygen, DO) to determine the annual net drawdown of inorganic matter or accumulation of organic matter (e.g., Weiss et al., 1979; Codispoti et al., 1982, 1986; Karl et al., 1991; Chipman et al., 1993; Yager et al., 1995; Bates et al., 1998a; Lee, 2001; Lee et al., 2002; Bates et al., 2006). Here, the cumulative change in surface layer concentrations of oxygen, inorganic nitrogen, phosphorus, silicate, or inorganic carbon is calculated by measurement of pre-bloom and post-bloom (early spring and midsummer) concentrations. Dividing this seasonal decrease in inventory by the amount of time between observations provides an integrated geochemical estimate of the rate of NCP which is conceptually equivalent to new production (Williams, 1993) estimated using NPP rates and f-ratios (Eppley and Peterson, 1979; Hansell et al., 1993; Springer et al., 1996; Varela and Harrison, 1999). Geochemical estimates of NCP can also be extrapolated across time and space without introduction of significant errors, making high-resolution basin-wide estimates of ecosystem production possible.

Few estimates of NCP have been conducted in the Bering Sea region, but there are historical studies of dissolved oxygen, inorganic nitrogen, and inorganic carbon drawdown (e.g., oxygen: Ivenakov, 1961; Azova, 1964; Sapohznikov and Naletova, 1995; inorganic nitrogen: Hansell et al., 1993; inorganic carbon: Codispoti et al., 1982, 1986). Estimation of NCP using oxygen and inorganic carbon drawdown have given the highest and lowest production rates, respectively (Table 2).

\section{Methods}

\subsection{Field sampling}

Physical, biogeochemical and biological measurements were made from the USCGC Healy during two cruises to the eastern Bering Sea in 2008. During the spring (April-May) and summer (June-July) cruises hydrographic stations were occupied on three east to west transect lines and one northsouth transect line (Fig. 1). The SL line was the northern most transect extending from near shore across the broad northern part of the shelf to a depth of $\sim 90 \mathrm{~m}$. The central line (MN) extended roughly from the southern tip of Nunivak Island across the shelf south of St. Matthew Island out to the shelf break $(2000 \mathrm{~m})$. The southern line (NP) extended from the southern tip of Nunivak Island southwest past the $150 \mathrm{~m}$ isobath. The north-south line followed the $70 \mathrm{~m}$ isobath for the length of the shelf southward from the SL line and ended southeast of the NP line. At the beginning of the spring cruise, sea ice cover was near $100 \%$ at all stations with the exception of some minor leads. During sampling of the SL, MN, and NP lines significant sea ice was present. Towards the end of the spring cruise, sea ice started to diminish. The southern half of the $70 \mathrm{~m}$ isobath line was ice free when sampled at the end of the cruise. During summer, the entire Bering Sea shelf was sea-ice free.

At each hydrographic station, conductivity-temperaturedepth (CTD) measurements were collected using a Seabird 911-plus system with dual temperature, salinity and oxygen sensors. Data were recorded during the downcast, with a decent rate of $15 \mathrm{~m} \mathrm{~min}^{-1}$ to a depth of $35 \mathrm{~m}$, and $30 \mathrm{~m} \mathrm{~min}^{-1}$ below that. Salinity calibration samples were collected on most casts and analyzed on a calibrated laboratory salinometer. Water samples for dissolved inorganic nutrients were collected at each station using Niskin bottles. Nutrient samples were analyzed onboard for dissolved phosphate, silicic acid, 
nitrate, nitrite, and ammonia using protocols of Gordon et al., (1993). In situ oxygen sensors were calibrated by the manufacturer prior to each cruise and dissolved oxygen samples were collected onboard for sensor ground truthing.

\subsection{Laboratory analysis}

All dissolved inorganic carbon (DIC) and total alkalinity (TA) samples were collected as suggested by the Guide to Best Practices for Ocean $\mathrm{CO}_{2}$ measurements (Dickson et al., 2007). Accordingly, seawater samples were drawn from Niskin bottles into pre-cleaned $\sim 300 \mathrm{~mL}$ borosilicate bottles. After collection, all samples were poisoned with $200 \mu \mathrm{L}$ of saturated aqueous mercuric chloride $\left(\mathrm{HgCl}_{2}\right)$ solution to halt biological alteration of DIC concentrations, sealed, and returned to the lab for analysis.

DIC/TA samples were analyzed using a highly precise and accurate gas extraction/coulometric detection system $\left(\sim 0.02 \%,<1 \mu\right.$ moles kg ${ }^{-1}$; Bates, 2001). The analytical system consists of a VINDTA 3C (Versatile Instrument for the Detection of Total Alkalinity) coupled to a $\mathrm{CO}_{2}$ coulometer (model 5012; UIC Coulometrics). Routine analyses of Certified Reference Materials (CRMs, provided by A.G. Dickson, Scripps Institution of Oceanography) and repeat sampling ensured that the accuracy of the DIC/TA measurements was within $0.05 \%$ and was stable over time.

\subsection{Estimates of NCP}

In our approach, we exploit seasonal changes in biological reactants and products (i.e., DIC), to estimate rates of NCP and account for minor factors such as gas exchange. NCP is calculated from the observed seasonal drawdown of DIC, according to the following equation (Williams, 1993):

$$
\begin{aligned}
\mathrm{NCP} & =\mathrm{DIC}_{\text {spring }}-\mathrm{DIC}_{\text {summer }} \\
& =\Delta \mathrm{DIC} \text { (moles } \mathrm{C} \text { per unit volume or area) }
\end{aligned}
$$

However, Eq. 1 reflects all seasonal modifications to DIC, while only a portion of the seasonal drawdown can be attributed to biological production in the Bering Sea. Sea-ice melt and terrestrial inputs can impact DIC concentrations in the upper mixed layer. For example, the addition of sea ice melt water with low concentrations of DIC effectively dilutes the surface layer, decreasing concentrations of DIC. Because NCP also decreases DIC concentrations in the euphotic zone (average depth $\sim 30 \mathrm{~m}$ ), ice melt can cause a false amplification of the NCP signal. This dilution of DIC concentrations can be corrected by normalizing DIC to a constant salinity of 35. The formation and dissolution of TA through biotic and geochemical processes can also cause changes in DIC. However, this effect can be corrected by measuring seasonal changes in TA (Lee, 2001; Codispoti et al., 1986). Approximately half of this change can be estimated to affect DIC concentrations: $\Delta \mathrm{DIC}_{\mathrm{Alk}}=0.5^{*}\left(\Delta \mathrm{Alk}+\Delta \mathrm{NO}_{3}\right)$. By subtracting this value from the change in normalized DIC, we render NCP the only significant process affecting seasonal changes in DIC concentrations (Mathis et al., 2009; Bates et al., 2005). The effects of air-sea $\mathrm{CO}_{2}$ flux and vertical diffusion on $\triangle \mathrm{DIC}$ are discussed in Sect. 5.3.

\section{Results}

\subsection{Frontal systems and hydrographic structure}

Temperature, salinity and density were used to identify frontal systems in both spring and summer. In spring, closely packed vertical isopycnals indicated the presence of a front approximately overlying the $50 \mathrm{~m}$ isobath, where lower coastal densities began to increase offshore. Temperature and salinity, in addition to density, identified a front at the $100 \mathrm{~m}$ isobath. Along the coast, waters were largely vertically mixed, exhibiting uniform temperature and salinity from the surface to the bottom. At the $50 \mathrm{~m}$ isobath front, waters transitioned to a two-layer system. Density frontal structure was least clearly defined along the SL line due weak tidal flows and resultant lack of mixing, and was most developed along the $\mathrm{MN}$ line. Density frontal structure was apparent between $58^{\circ} \mathrm{N}$ and $60^{\circ} \mathrm{N}$ along the $70 \mathrm{~m}$ line, with fresher surface water and colder bottom temperatures to the north.

Summertime frontal systems were more clearly developed than in spring. Two-layer stratification was evident in all three properties (temperature, salinity, and density). A front overlying the $50 \mathrm{~m}$ isobath was clearly defined by temperature throughout the entire water column along all lines. In contrast to spring, where well mixed coastal waters transitioned to a two layer system much further seaward, the summertime transition to a two layer system occurred approximately at this inshore front. Rapidly changing temperature gradients identified a second front at approximately the $90 \mathrm{~m}$ isobath along the MN and NP lines, although this structure was not apparent along the SL line and was much broader than the inshore front. Summertime variance along the $70 \mathrm{~m}$ isobath was minimal, although a broad transitional zone in temperature was apparent between $58.5^{\circ} \mathrm{N}$ and $59.5^{\circ} \mathrm{N}$, and isohalines showed a front occurring at approximately $61^{\circ} \mathrm{N}$.

Stratification isolated a layer of cold bottom water between the inner front and the middle front during summer. This cold pool extended from the bottom to approximately $25 \mathrm{~m}$ below the surface on the MN and NP lines. A low salinity feature was also apparent in the summer surface layer seaward of the inner front and centered over the central front, likely due to the influences of fresh water from ice melt in May and June. With the weak winds of late spring, this fresher surface water is not mixed vertically and thus a fresh water lens $(\sim 20 \mathrm{~m}$ deep) contributes to the vertical structure over the northern shelf. 


\subsection{Spatial and seasonal distributions of inorganic nutrients: nitrate, phosphate, silicate, and dissolved oxygen}

Spatially, changes in inorganic nutrients and DO concentration coincided with frontal transition zones. In particular, nutrient concentrations followed isohalines very closely in spring, and isothermal lines in summer. DO concentrations followed density structure, but did not adhere to isohalines or isothermals as clearly as inorganic nutrient concentrations.

Three broad zones were apparent in both seasons, separated by the fronts. In spring, inorganic nutrient concentrations inshore of the innermost front were lowest (nitrate: $\sim 3.5 \mu$ moles kg ${ }^{-1}$; phosphate: $\sim 1.2 \mu$ moles $\mathrm{kg}^{-1}$; silicate: $\sim 17 \mu$ moles $\mathrm{kg}^{-1}$ ), while DO concentrations were highest in this region $\left(\sim 355 \mu\right.$ moles $\left.\mathrm{kg}^{-1}\right)$. Nutrient concentrations increased off the shelf seaward of this front and peaked in bottom waters of the outer domain (nitrate: $\sim 28 \mu$ moles $\mathrm{kg}^{-1}$; phosphate: $\sim 2 \mu$ moles $\mathrm{kg}^{-1}$; silicate: $\sim 40 \mu$ moles $\mathrm{kg}^{-1}$ ) where DO concentrations were lowest $\left(\sim 300 \mu\right.$ moles $\left.\mathrm{kg}^{-1}\right)$. Springtime inorganic nitrogen concentrations were fairly uniform with depth, while oxygen concentrations exhibited a two-layer system seaward of the $100 \mathrm{~m}$ isobath front. Along the shelf, inorganic nutrient concentrations decreased to the south (e.g., nitrate: $15 \mu$ moles $\mathrm{kg}^{-1}$ to $\sim 10 \mu$ moles $\mathrm{kg}^{-1}$ ) while oxygen concentrations increased $\left(\sim 325 \mu\right.$ moles $\mathrm{kg}^{-1}$ to $\sim 415 \mu$ moles $\mathrm{kg}^{-1}$ ), as was apparent both on the $70 \mathrm{~m}$ line and in the variability between concentrations along the crossshelf lines (NP, MN, and SL). There were two low-nutrient (e.g., nitrate: $\sim 5 \mu$ moles $\mathrm{kg}^{-1}$ ) features in the surface layer along the $70 \mathrm{~m}$ line, at approximately $59^{\circ} \mathrm{N}$ and $56^{\circ} \mathrm{N}$.

Summertime inorganic nutrient concentrations were consistently lower than springtime concentrations. Inshore of the innermost front, inorganic nitrogen and silicate concentrations were completely depleted throughout the entire water column. Seaward of this front, nitrate and silicate concentrations were still depleted in the surface layer, although higher concentrations of these nutrients were observed in bottom waters. Phosphate concentrations increased off the shelf, but were not depleted below the detection limit inshore of the inner front or in the surface layer, except in the surface layer near the shelf break. In summer, subsurface zones $(\sim 15 \mathrm{~m}$ to $50 \mathrm{~m})$ of high oxygen concentration $\left(\sim 400 \mu\right.$ moles $\left.\mathrm{kg}^{-1}\right)$ were present across the entire shelf on the SL and MN lines. Along the NP line, oxygen concentrations were highest throughout the water column in the Coastal Domain $\left(\sim 380 \mu\right.$ moles $\left.\mathrm{kg}^{-1}\right)$. In general, oxygen concentrations were higher in summer in the upper $50 \mathrm{~m}$ compared to spring, but were lower relative to spring concentrations in the bottom waters over the shelf.

\subsection{Spatial and seasonal distributions of DIC}

Figure 3 shows the spatial distribution of spring DIC concentrations averaged over the upper $30 \mathrm{~m}$ of the shelf. The

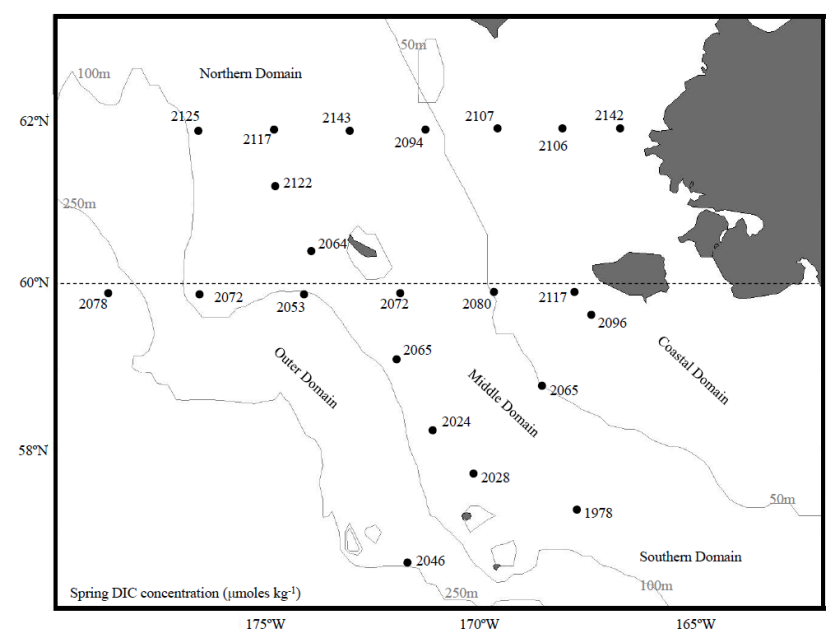

Fig. 3. Spring DIC concentrations ( $\mu$ moles $\mathrm{kg}^{-1}$ ) averaged over the upper $30 \mathrm{~m}$ of the water column across the shelf.

highest surface layer concentrations were found in the inner domain and the northern regions of the Middle Domain ( 2100-2150 $\mu$ moles kg ${ }^{-1}$ ). The lowest surface layer concentrations occurred in the Middle and Outer Domains to the south $\left(\sim 2025 \mu\right.$ moles $\left.\mathrm{kg}^{-1}\right)$. Comparison of the variation of DIC concentrations with depth along the three sampling lines (Fig. 4a-d) shows that concentrations throughout the water column were highest in the northern region of the shelf $\left(\sim 2130 \mu\right.$ moles $\left.\mathrm{kg}^{-1}\right)$. Concentrations along the $70 \mathrm{~m}$ isobath line (Fig. 4d) also showed higher concentrations north of $61^{\circ} \mathrm{N}$.

Across the shelf, there were three distinct regions of DIC concentrations during spring. Concentrations on the inner shelf were fairly constant with depth. Coastal Domain DIC concentrations rapidly decreased by $\sim 50 \mu$ moles $\mathrm{kg}^{-1}$ through the inner front to the Middle Domain. Middle Domain DIC concentrations were relatively low along all lines, but particularly in the upper $10 \mathrm{~m}$ along the SL line. Seaward of the middle front, DIC concentrations increased, and stratified into a two-layer system. DIC concentrations increased more rapidly below $40 \mathrm{~m}$ to $\sim 2125 \mu$ moles $\mathrm{kg}^{-1}$ at $100 \mathrm{~m}$, and to $\sim 2225 \mu$ moles $\mathrm{kg}^{-1}$ at $250 \mathrm{~m}$.

Summertime concentrations of DIC averaged over the upper $30 \mathrm{~m}$ (Fig. 5) were on average lower than springtime concentrations by $\sim 90 \mu$ moles kg ${ }^{-1}$ and decreased most in the middle and outer domains. Inshore, concentrations of DIC were moderate $\left(\sim 2050 \mu\right.$ moles kg $\left.{ }^{-1}\right)$ and constant with depth. In contrast to spring, summer DIC concentrations horizontally stratified into a two layer system in the middle domain (Fig. 6a-d). In the middle domain, the upper layer $(0-30 \mathrm{~m})$ had a dramatically lower concentration $\left(\sim 1900 \mu\right.$ moles $\left.\mathrm{kg}^{-1}\right)$ than the slightly westward bottom $40 \mathrm{~m}$ of water $\left(\sim 2200 \mu\right.$ moles $\left.\mathrm{kg}^{-1}\right)$. This stratification was not present seaward of the middle front along the SL line, where DIC concentrations were constant with 

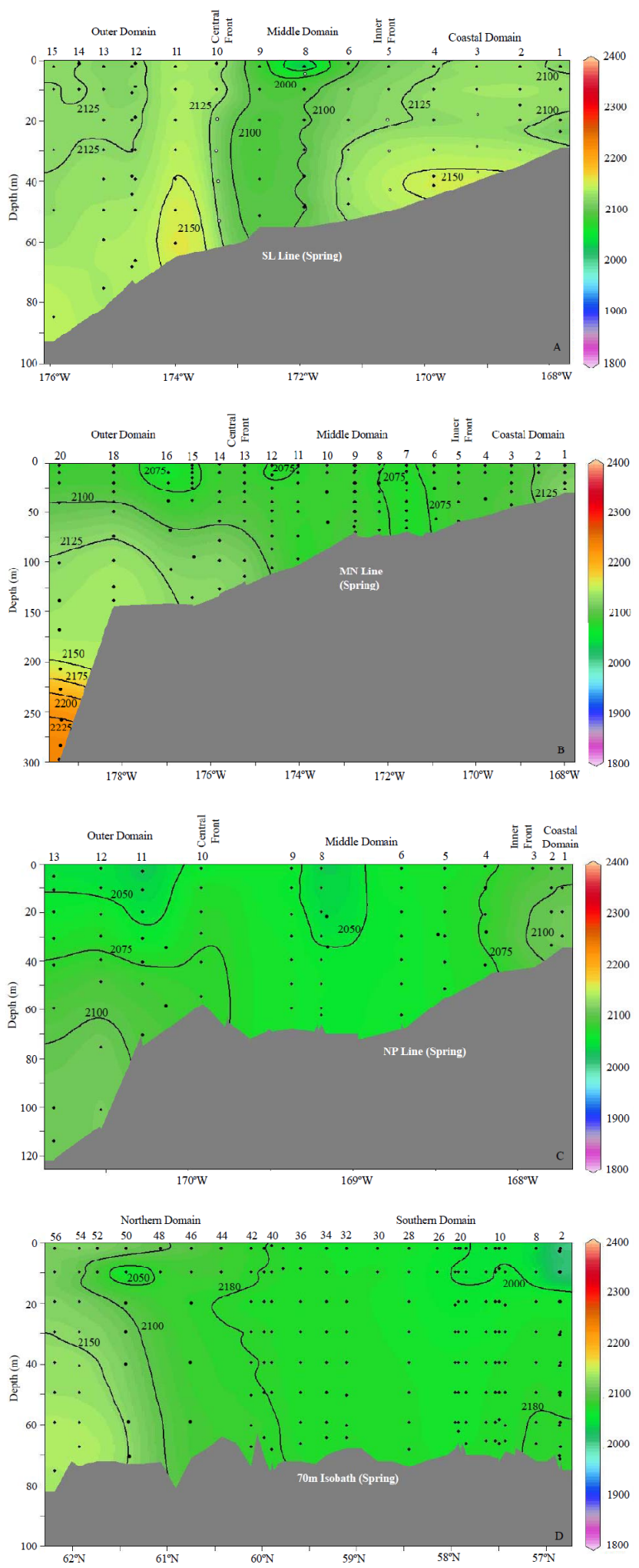

Fig. 4. Spring DIC concentrations $\left(\mu\right.$ moles $\mathrm{kg}^{-1}$ ) along the four lines. The domains and fronts as well as station numbers are shown across the top of each figure. A) SL line. B) MN Line. C) NP Line. D) $70 \mathrm{~m}$ Line.

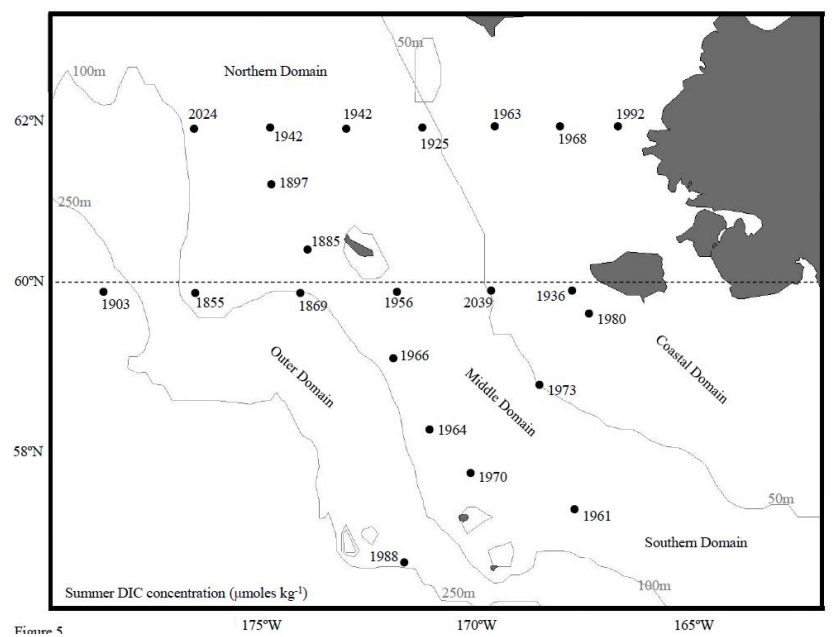

Fig. 5. Summer DIC concentrations ( $\mu$ moles $\mathrm{kg}^{-1}$ ) averaged over the upper $30 \mathrm{~m}$ across the shelf.

depth $\left(\sim 2050 \mu\right.$ moles $\left.\mathrm{kg}^{-1}\right)$. Along the MN and NP lines, Outer Domain DIC concentrations increased with depth ( $\sim 2050 \mu$ moles $\mathrm{kg}^{-1}$ at $0 \mathrm{~m}$ to $2250 \mu$ moles $\mathrm{kg}^{-1}$ at $250 \mathrm{~m}$ ).

\subsection{Spatial and seasonal distributions of alkalinity}

In spring, TA ranged from $2150 \mu$ moles $\mathrm{kg}^{-1}$ to $2300 \mu$ moles $\mathrm{kg}^{-1}$ over the shelf, with the lowest concentrations observed inshore of the inner front along the $\mathrm{MN}$ line and the highest concentrations observed in offshore bottom waters. Beyond the shelf break, high concentrations $\left(\sim 2450 \mu\right.$ moles kg$\left.{ }^{-1}\right)$ were observed at depth and correlated with high salinity water. Inshore of the inner front, TA was constant with depth except along the MN line. Concentrations were higher along the NP line in the south $\left(\sim 2235 \mu\right.$ moles $\left.\mathrm{kg}^{-1}\right)$ than along the SL line in the north $\left(\sim 2220 \mu\right.$ moles $\left.\mathrm{kg}^{-1}\right)$. Along the MN line, surface layer concentrations were $\sim 15 \mu$ moles $\mathrm{kg}^{-1}$ lower than bottom water concentrations. Through the inner front, TA was low along the SL line $\left(\sim 2180 \mu\right.$ moles $\left.\mathrm{kg}^{-1}\right)$ and NP line $\left(\sim 2170 \mu\right.$ moles $\left.\mathrm{kg}^{-1}\right)$. Seaward of this front, TA stratified into a two-layer system and increased along the SL and MN lines but decreased along the NP line. Along all lines, concentrations increased with depth. TA appeared to follow frontal structure at the $100 \mathrm{~m}$ isobath along the $\mathrm{MN}$ line, but this feature was not evident in other lines. Along the $70 \mathrm{~m}$ line, TA exhibited a two-layer system south of $58.5^{\circ} \mathrm{N}$, with surface layer concentrations $\sim 20 \mu$ moles $\mathrm{kg}^{-1}$ lower than bottom water concentrations.

Summertime concentrations of TA closely followed isohalines along all lines and exhibited a wider range than in spring $\left(\sim 2050 \mu\right.$ moles $\mathrm{kg}^{-1}$ to $2400 \mu$ moles kg $\left.{ }^{-1}\right)$. Inshore of the inner front, concentrations were stratified along the SL line, where surface layer concentrations averaged $\sim 2135 \mu$ moles kg ${ }^{-1}$ and increased to $\sim 2170 \mu$ moles kg $\mathrm{kg}^{-1}$ 
Table 3. Spring and Summer nDIC concentrations, the seasonal drawdown of normalized DIC, correction factor applied for the formation and dissolution of calcium carbonate minerals $\left(-0.5^{*}\left(\Delta \mathrm{TA}+\Delta \mathrm{NO}_{3}\right)\right)$, rates of $\mathrm{NCP}$ based on the seasonal drawdown of nDIC $(\mathrm{NCP} \mathrm{nDIC})$, and rates of NCP based on the seasonal drawdown of nDIC and corrected for the formation and dissolution of calcium carbonate minerals $\left(\mathrm{NCP}_{\mathrm{nDIC}-\mathrm{C}}\right)$ by station in 2008 . Drawdown of $\mathrm{nDIC}$ was on average $\sim 90 \mu \mathrm{moles} \mathrm{kg}^{-1}$, and was highest in the middle and outer domains in the region of the greenbelt, where $\mathrm{NCP}_{\mathrm{nDIC}}$ and $\mathrm{NCP}_{\mathrm{nDIC}-\mathrm{C}}$ were also highest.

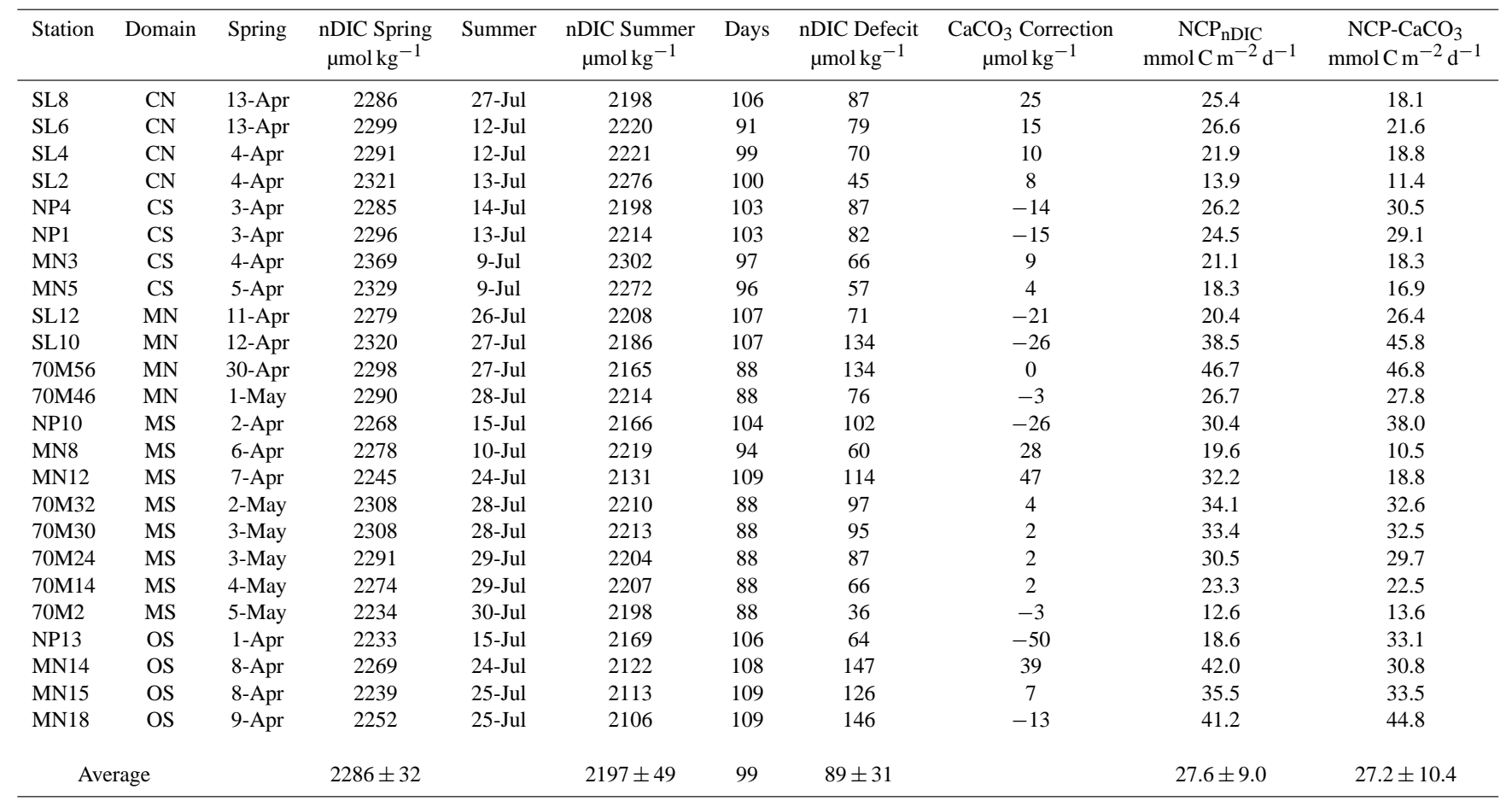

in bottom waters. Along the MN line and NP lines, TA was constant with depth at $\sim 2160 \mu$ moles $\mathrm{kg}^{-1}$. Concentrations decreased through the inner front along the MN line $\left(\sim 2140 \mu\right.$ moles $\left.\mathrm{kg}^{-1}\right)$, but increased along the SL and NP lines. Between the $50 \mathrm{~m}$ And $100 \mathrm{~m}$ isobath fronts, TA was stratified along the SL and MN lines, with higher concentrations in bottom waters. Along the MN line, surface layer concentrations were particularly low $\left(\sim 2060 \mu\right.$ moles kg $\left.{ }^{-1}\right)$. Seaward of the $100 \mathrm{~m}$ isobath front, concentrations were stratified along all lines and peaked in bottom waters off the shelf. Along the $70 \mathrm{M}$ line, summertime TA was constant with depth in southern regions $\left(\sim 2160 \mu\right.$ moles $\left.\mathrm{kg}^{-1}\right)$. North of $59^{\circ} \mathrm{N}$, TA was low in surface waters $\left(\sim 2100 \mu\right.$ moles $\left.\mathrm{kg}^{-1}\right)$ and increased with depth $\left(\sim 2185 \mu\right.$ moles $\left.\mathrm{kg}^{-1}\right)$.

\section{Discussion}

\subsection{Rates of Net Community Production}

As discussed earlier, we normalized DIC concentrations in spring and summer to a salinity of 35 in the estimate of NCP rates (Table 3). In the spring, nDIC concentrations ranged from $2230 \mu$ moles $\mathrm{kg}^{-1}$ to $2330 \mu$ moles kg-1, with an average nDIC concentration of $2284 \mu$ moles kg-1.
In summer, nDIC concentrations were lower, ranging from $2100 \mu \mathrm{mol} \mathrm{kg}{ }^{-1}$ to $2280 \mu$ moles $\mathrm{kg}^{-1}$, with an average nDIC concentration of $2197 \mu$ moles $\mathrm{kg}^{-1}$. Summertime drawdown was on average $\sim 90 \mu$ moles $\mathrm{kg}^{-1}$ (see Table 3), and was highest in the Middle and Outer Domains in the region of the "Green Belt".

The corrective effects of normalization on DIC concentrations can be seen in Fig. 7a-d. Here, DIC and nDIC are plotted relative to salinity in both spring and summer. While the relationship between nDIC and salinity (Fig. 7c and d) was similar to the relationship between DIC and salinity (Fig. 7a and $b$ ), the summertime dispersion of nDIC was much more vertically distributed. In Fig. 7c and d, the horizontal dispersion of DIC concentrations once due to changing salinity has been removed by normalization, and any dilutive effects on DIC concentrations have been eliminated. As a result, the effects of biological processes and in-situ calcium carbonate mineral formation are isolated. In spring (Fig. 7c), nDIC concentrations were constrained within a small range of salinities. In summer (Fig. 7d), some nDIC concentrations were drawn down by primary production and carbonate mineral formation, causing an increase in dispersion closer to the $\mathrm{x}$-axis. Water column and sedimentary remineralization and carbonate mineral dissolution raised concentrations 

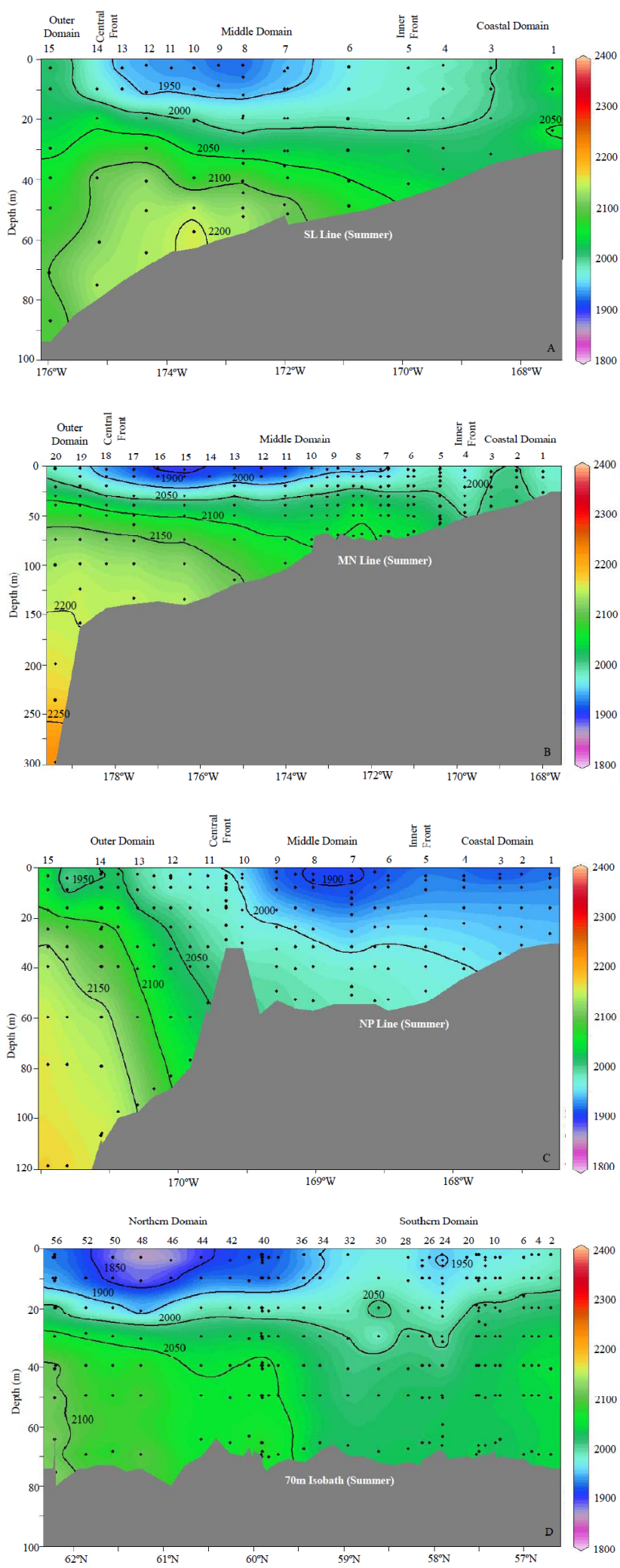

Fig. 6. Summer DIC concentrations ( $\mu$ moles $\mathrm{kg}^{-1}$ ) along the four transect lines shown in Fig. 1. The domains and fronts as well as station numbers are shown across the top of each figure. A) SL line. B) MN Line. C) NP Line. D) $70 \mathrm{~m}$ Line.
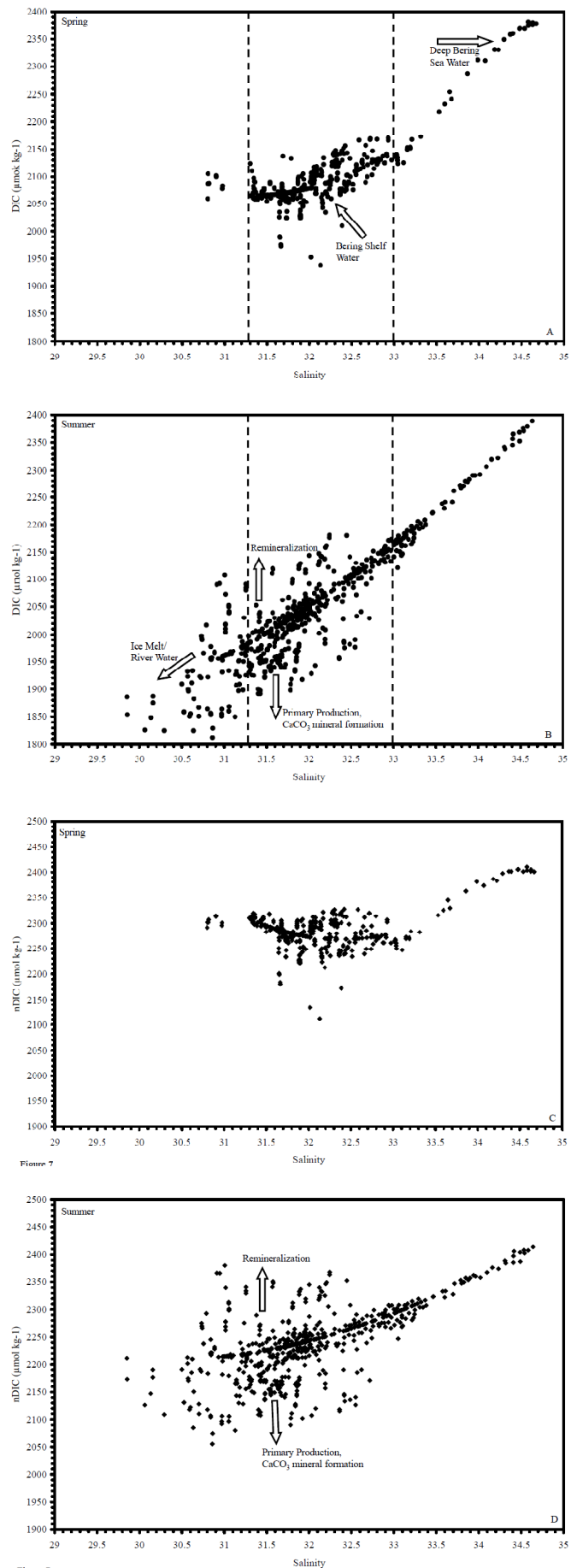

Fig. 7. Spring and summer concentrations of DIC $\left(\mu\right.$ moles $\left.\mathrm{kg}^{-1}\right)$ relative to salinity (A) Spring. Bering shelf water salinity ranged from 31.3 to 33 , with concentrations of DIC from $1950 \mu$ moles $\mathrm{kg}^{-1}$ to $2170 \mu$ moles $\mathrm{kg}^{-1}$, while deep Bering Sea salinity ranged from salinity $33-35$, with concentrations of DIC from $2140 \mu$ moles $\mathrm{kg}^{-1}$ to $2380 \mu$ moles $\mathrm{kg}^{-1}$. (B) Summer. DIC concentrations $\left(\mu\right.$ moles $\left.\mathrm{kg}^{-1}\right)$ relative to salinity. Arrows show the relative influence of freshwater input, on both salinity and DIC, whereas productivity decreased DIC and remineralization increased DIC relative to salinity. (C) Spring. Most nDIC concentrations fell within the range of salinities of 31 and 33. (D) Summer. nDIC concentrations relative to salinity decreased from spring. $\mathrm{NCP}$ and carbonate mineral formation draws springtime clustering down as DIC is consumed; remineralization distributes the clustering up, as DIC is produced by biological processes and carbonate mineral dissolution. The effects of each process are shown by arrows. 

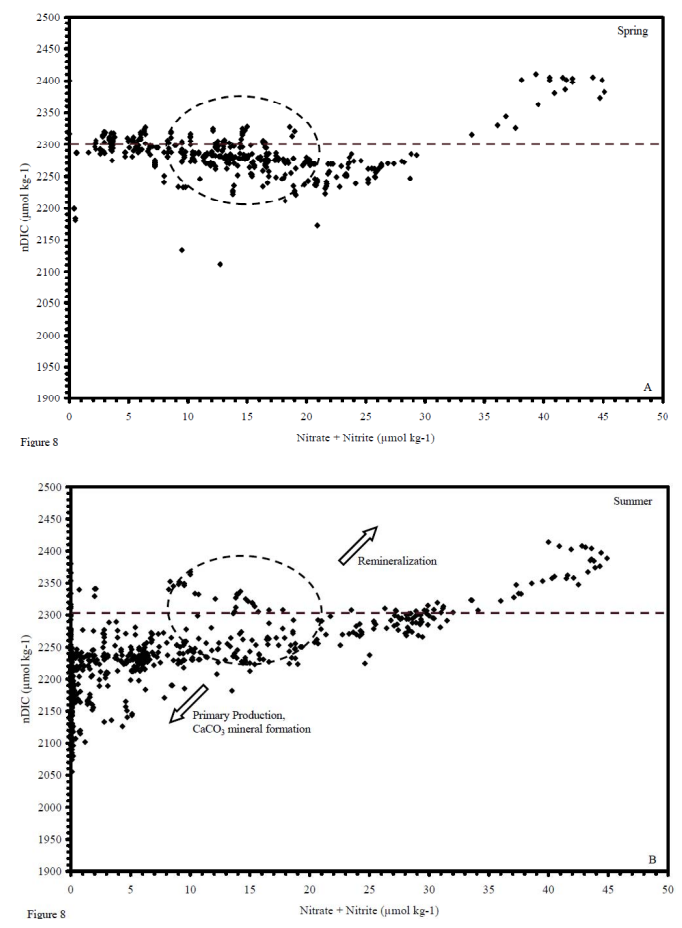

Fig. 8. Spring and summer concentrations of nDIC ( $\mu$ moles $\mathrm{kg}^{-1}$ ) relative to nitrate+nitrite $\left(\mu\right.$ moles $\left.\mathrm{kg}^{-1}\right)$. (A) Spring. For nearly all concentrations of nitrate+nitrite, nDIC ranged from $\sim 2225 \mu$ moles kg $^{-1}$ to $2350 \mu$ moles kg ${ }^{-1}$. Average spring concentration $\left(2300 \mu\right.$ moles $\left.\mathrm{kg}^{-1}\right)$ is marked by the dotted line. (B) Summer. nDIC concentrations decreased with respect to nitrate, ranging from $\sim 2050 \mu$ moles $\mathrm{kg}^{-1}$ to $2350 \mu$ moles $\mathrm{kg}^{-1}$. The springtime average $\left(2300 \mu\right.$ moles $\left.\mathrm{kg}^{-1}\right)$ is also plotted here, showing that most summertime points fall below the springtime average due to primary production and carbonate mineral formation.

of nDIC in bottom waters, increasing the range of summertime dispersion in the opposite direction.

NCP is also apparent in Fig. 8a and b, where nDIC is plotted relative to inorganic nitrogen. In spring (Fig. 8a), average nDIC concentration was approximately $2300 \mu$ moles kg-1, as indicated by the dotted line, and most nDIC concentrations were well constrained within a small range of inorganic nitrogen concentrations, indicated by the dotted circle. In Figure $8 \mathrm{~B}$, the springtime average and clustering location is also shown relative to the summertime nDIC concentrations. Dispersion beneath the dotted line and dotted circle increased due to biological processes and carbonate mineral formation. As production and carbonate mineral dynamics affect both axes, the vectors are skewed: primary production decreases both nDIC and inorganic nitrogen, and increases dispersion in the direction of the origin, where as the production of nDIC and inorganic nitrogen through water column and sedimentary oxidation of organic matter increases dispersion away from the origin.
Inorganic nitrogen concentrations decreased to zero in summer at most locations in the surface layer and caused an accumulation of points at and near the y-axis. In areas where nitrate is not limiting, such as the HNLC middle and outer domains, nDIC concentrations are not clustered near the axes, but do accumulate below the spring average concentration. There is also an increased dispersion to the upper right, due to some oxidation of organic matter in bottom waters. This can be seen as an amplified DIC signal in the bottom waters (most obvious in Fig. 6a) beneath the areas of highest drawdown in the surface waters. The coupling of $\mathrm{NCP}$ at the surface to increases of DIC in bottom waters has also been observed in the Chukchi Sea (Bates and Mathis, 2009). Similarly, this remineralized DIC lowers the $\mathrm{pH}$ of these bottom waters suppressing the carbonate mineral saturation states (Mathis et al., 2010).

The relationships between nDIC and DO in spring and summer are shown in Fig. 9a and b. The relationship between nDIC and DO is tightly clustered in spring, shown by the dotted circle. The cumulative effects of biological processes and carbonate mineral dynamics cause the increase in dispersion seen in summer, compared to the springtime cluster (again indicated by the dotted circle). Production also affects both of these axes but the vectors are opposite to those for the inorganic nitrogen vs. nDIC: production produces dissolved oxygen while decreasing nDIC, and thus draws points towards the $\mathrm{x}$-axis and away from the $\mathrm{y}$-axis, while nutrient regeneration increases $\mathrm{nDIC}$ and decreases DO, drawing points towards the $\mathrm{y}$ axis but away from the $\mathrm{x}$ axis.

NCP estimates integrated over the upper $30 \mathrm{~m}$ calculated from nDIC $\left(\mathrm{NCP}_{\mathrm{nDIC}}\right)$ according to the equation 1 are shown in Table 3 . The average time between station occupations was $\sim 100$ days leading to an average nDIC drawdown of $\sim 90 \mu$ moles $\mathrm{kg}^{-1}$, with a subsequent average NCP of $27.6 \pm 9$ mmoles $\mathrm{C} \mathrm{m}^{-2} \mathrm{~d}^{-1}$. However, rates of NCP varied across the biogeochemical domains (see Table 4). $\mathrm{NCP}_{\mathrm{nDIC}}$ was lowest in the northern region of the inner domain $\left(19.3 \pm 6.0\right.$ mmoles $\left.\mathrm{C} \mathrm{m}^{-2} \mathrm{~d}^{-1}\right)$, and highest in the northern region of the middle domain $\left(37.4 \pm 8.2\right.$ mmoles $\left.\mathrm{C} \mathrm{m}^{-2} \mathrm{~d}^{-1}\right)$. Limited sampling prevented calculation of a value for the northern section of the outer domain, but $\mathrm{NCP}_{\mathrm{nDIC}}$ in the southern half of the outer domain was similar to the high $\mathrm{NCP}_{\mathrm{nDIC}}$ in the northern section of the middle domain $\left(34.2 \pm 10.7\right.$ mmoles $\left.\mathrm{C} \mathrm{m}^{-2} \mathrm{~d}^{-1}\right)$.

Estimating NCP based on nDIC alone appears insufficient, however. Figure 10 shows the change in TA in the upper $30 \mathrm{~m}$ between spring and summer. In general, TA was lower in summer except in a few areas. Because of this seasonal change, applying the correction factor for the formation and dissolution of TA, as discussed in Sect. 3.3, causes a change in NCP estimates. As seen in Table 3, the change in TA was highly variable across the shelf. Application of the correction factor for these changes in TA increases NCP in the northern coastal domain ( $\sim 4.5$ mmoles $\mathrm{C} \mathrm{m}^{-2} \mathrm{~d}^{-1}$ on average) and the southern 
Table 4. NCP in mmoles $\mathrm{C} \mathrm{m}^{-2} \mathrm{~d}^{-1}$ by domain in 2008, where NC indicates the northern coastal domain, SC indicates the southern coastal domain, NM indicates the northern middle domain, SM indicates the southern middle domain, and SO indicates the southern outer domain. NCP estimates were based on calcium-carbonate corrected seasonal drawdown of nDIC $\left(\mathrm{NCP}_{\mathrm{nDIC}-\mathrm{C}}\right)$, $\mathrm{TN}$ (Nitrate $\left.+\mathrm{Nitrite}\right)$ at a ratio of 106C:16N ( $\left.\mathrm{NCP}_{\mathrm{TN}}\right)$, Phosphate at a ratio of $106 \mathrm{C}: 1 \mathrm{P}\left(\mathrm{NCP}_{\mathrm{P}}\right)$, Silicate at a ratio of 106C:15Si (Brzezinski, 1985; $\left.\mathrm{NCP}_{\mathrm{Si}-\mathrm{B}}\right)$, and Silicate at a ratio of 106C:40Si (Aguilar-Islas et al., 2007; $\mathrm{NCP}_{\mathrm{Si}-\mathrm{A}}$ ). Error listed is one standard deviation from the mean.

\begin{tabular}{lcccccc}
\hline Domain & $\begin{array}{c}\mathrm{NCP}_{\mathrm{nDIC}} \\
\mathrm{mmol} \mathrm{C} \mathrm{m}^{-2} \mathrm{~d}^{-1}\end{array}$ & $\begin{array}{c}\mathrm{NCP}_{\mathrm{nDIC}-\mathrm{C}} \\
\mathrm{mmol} \mathrm{C} \mathrm{m}^{-2} \mathrm{~d}^{-1}\end{array}$ & $\begin{array}{c}\mathrm{NCP}_{\mathrm{TN}} \\
\mathrm{mmol} \mathrm{C} \mathrm{m}^{-2} \mathrm{~d}^{-1}\end{array}$ & $\begin{array}{c}\mathrm{NCP}_{\mathrm{PO} 4} \\
\mathrm{mmol} \mathrm{C} \mathrm{m}^{-2} \mathrm{~d}^{-1}\end{array}$ & $\begin{array}{c}\mathrm{NCP}_{\mathrm{Si}-\mathrm{B}} \\
\mathrm{mmol} \mathrm{C} \mathrm{m}^{-2} \mathrm{~d}^{-1}\end{array}$ & $\begin{array}{c}\mathrm{NCP}_{\mathrm{Si}-\mathrm{A}} \\
\mathrm{mmol} \mathrm{C} \mathrm{m}^{-2} \mathrm{~d}^{-1}\end{array}$ \\
\hline $\mathrm{NC}$ & $22.0 \pm 6$ & $17.5 \pm 4$ & $14.4 \pm 5$ & $28.9 \pm 4$ & $53.2 \pm 21$ & $20 \pm 8$ \\
$\mathrm{SC}$ & $22.5 \pm 4$ & $23.7 \pm 7$ & $4.5 \pm 2$ & $26 \pm 7$ & $23 \pm 5$ & $8.7 \pm 2$ \\
$\mathrm{NM}$ & $33.1 \pm 12$ & $36.7 \pm 11$ & $28.6 \pm 3$ & $37.0 \pm 4$ & $79.7 \pm 17$ & $29.9 \pm 6$ \\
$\mathrm{SM}$ & $27.0 \pm 8$ & $24.8 \pm 10$ & $15.6 \pm 15$ & $23.4 \pm 16$ & $44.0 \pm 30$ & $16.5 \pm 11$ \\
SO & $35.3 \pm 11$ & $35.5 \pm 6$ & $40.5 \pm 3$ & $36.5 \pm 2$ & $87.0 \pm 4$ & $32.6 \pm 2$ \\
Shelf & $27.6 \pm 9$ & $27.2 \pm 4$ & $19.9 \pm 15$ & $29.2 \pm 11$ & $55.1 \pm 30$ & $20.7 \pm 11$ \\
\hline
\end{tabular}
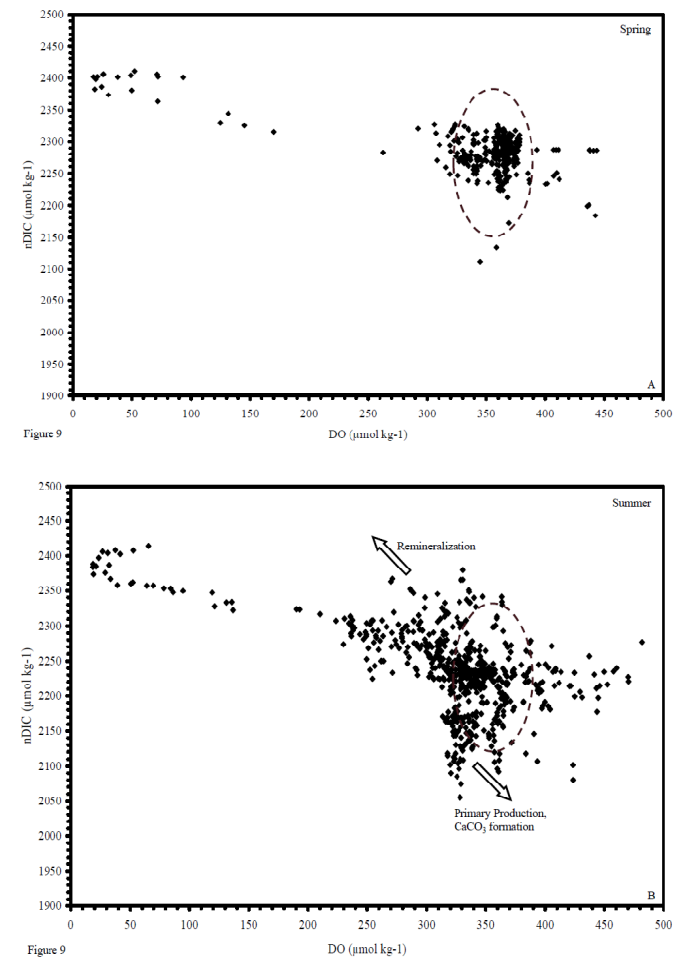

Fig. 9. Spring and summer concentrations of nDIC $\left(\mu\right.$ moles $\left.\mathrm{kg}^{-1}\right)$ relative to spring and summer concentrations of DO $\left(\mu\right.$ moles $\left.\mathrm{kg}^{-1}\right)$ (A) Spring. Most points clustered within the highlighted area of DO concentrations between 300 and $400 \mu$ moles kg ${ }^{-1}$, and DIC concentrations between $\sim 2200$ and $2450 \mu$ moles kg ${ }^{-1}$. (B) Summer. DIC concentrations were much less clustered and mostly lower relative to DO concentrations in spring. For ease of comparison, the springtime cluster is also shown in this figure (highlighted area). The arrows show the effects of primary production and carbonate mineral dynamics between station occupations: NCP draws values down and to the right, as surface layer DIC is consumed and DO is produced; remineralization draws values up and to the left as DIC is produced and DO is consumed.

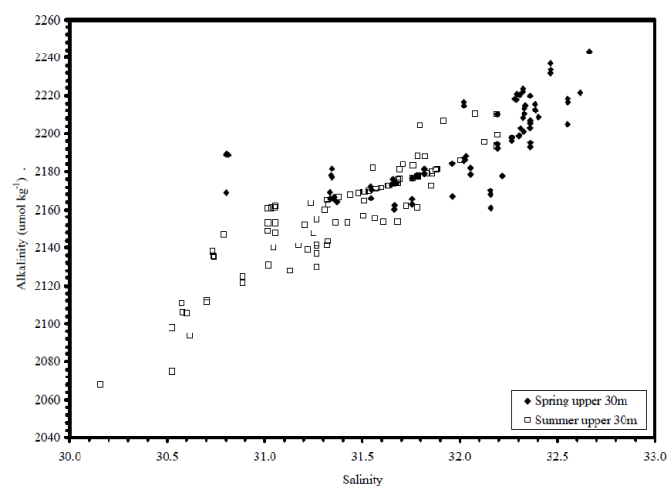

Fig. 10. Spring and summer concentrations of TA ( $\mu$ moles kg ${ }^{-1}$ ) in the upper $30 \mathrm{~m}$ of the water column. Overall, TA concentrations were lower in summer than in spring, although some summer values were higher. This seasonal change necessitates the application of a correction factor to NCP estimates which accounts for the formation and dissolution of TA.

middle domain ( $\sim 2.2$ mmoles $\mathrm{C} \mathrm{m}^{-2} \mathrm{~d}^{-1}$ on average), while the correction decreases NCP in the southern coastal domain $\left(-1.1\right.$ mmoles $\mathrm{C} \mathrm{m}^{-2} \mathrm{~d}^{-1}$ on average), the northern middle domain ( -3.6 mmoles $\mathrm{C} \mathrm{m}^{-2} \mathrm{~d}^{-1}$ on average), and the southern outer domain $\left(-1.2\right.$ mmoles $\mathrm{C} \mathrm{m}^{-2} \mathrm{~d}^{-1}$ on average). Overall, shelf-wide NCP estimates decreased by 0.4 mmoles $\mathrm{C} \mathrm{m}^{-2} \mathrm{~d}^{-1}$. The shelf-wide distribution of carbonate-corrected $\mathrm{NCP}$ values $\left(\mathrm{NCP}_{\mathrm{nDIC}-\mathrm{C}}\right)$ can be seen in Fig. 11.

$\mathrm{NCP}_{\mathrm{nDIC}-\mathrm{C}}$ in the northern Coastal Domain may have been low because of the low initial stock of macronutrients relative to the remainder of the shelf. Although waters over the inner domain were often mixed to depth, the Coastal Domain is the shallowest of the three along-shelf zones. Despite mixing the available stock of nutrients in this smaller domain could not sustain production, and macronutrients were completely depleted in both the northern and southern halves of this domain. $\mathrm{NCP}_{\mathrm{nDIC}-\mathrm{C}}$ in the southern coastal 
domain may have been bolstered by additional nitrate provided through activity of a surface layer nutrient regeneration loop.

The high $\mathrm{NCP}_{\mathrm{nDIC}-\mathrm{C}}$ of the Middle and Outer Domains may be due to the confluence of shelf-derived iron and basinderived nutrients at the shelf-break front that provide an ideal environment for primary production. Eddies spawned along the shelf break and proximity to the basin further supply nutrients well into the growing season, sustaining longer periods of primary production relative to the zones to the east and west. Furthermore, POC produced in this region is rapidly exported off the shelf, reducing any remineralization feedback that might be seen in other domains.

NCP can also be calculated using the drawdown of other active components of photosynthesis (Williams, 1993; Table 2). By measuring the seasonal change in concentrations of nitrate + nitrite, phosphate and silicate (Table 4), we can provide some additional insights to NCP estimates across the shelf. Using a C:N ratio of 106:16, we found that NCP estimates based on nitrate $\left(\mathrm{NCP}_{\mathrm{TN}}\right)$ were $\sim 8$ mmoles $\mathrm{C} \mathrm{m}^{-2} \mathrm{~d}^{-1}$ less than $\mathrm{NCP}_{\mathrm{nDIC}-\mathrm{C}}$, suggesting an elevated consumption of carbon compared to that of nitrate. This condition has been observed in a variety of other high export coastal systems (e.g., Sambrotto et al., 2003), and attributed to the production of nitrogen-poor, carbon-rich organic matter, and in-situ biological processes that recycle carbon less efficiently than nitrogen. The particularly low $\mathrm{NCP}_{\mathrm{TN}}$ values found in the southern coastal domain suggest that this regeneration loop does play a large role in this particular region. It has also been suggested in previous works that using a limiting nutrient to estimate carbon production may result in significant underestimations of NCP (Sambrotto et al., 2003). In contrast to the remainder of the shelf, $\mathrm{NCP}_{\mathrm{TN}}$ values were higher than $\mathrm{NCP}_{\mathrm{nDIC}-\mathrm{C}}$ in the southern region of the outer domain, suggesting an elevated consumption of nitrate. This may be due to the reverse of processes suggested above: the production of nitrate-rich organic matter, or in-situ processes which recycle carbon more efficiently than nitrate. It is also possible that $\mathrm{NCP}_{\mathrm{nDIC}-\mathrm{C}}$ is low due to TA production in excess of our correction factor. As was noted earlier, the outer domain of the southernmost sampling line (NP) was the only region where TA increased from spring to summer.

$\mathrm{NCP}$ values calculated from phosphate $\left(\mathrm{NCP}_{\mathrm{P}}\right)$ were consistent with $\mathrm{NCP}_{\mathrm{nDIC}-\mathrm{C}}$, although they were in all cases slightly higher. This suggests that phosphate is being consumed in excess of the Redfield Ratio. However, because the deviation in NCP measurements is so small $\left(\sim 1\right.$ mmoles $\left.\mathrm{C} \mathrm{m}^{-2} \mathrm{~d}^{-1}\right)$, it is difficult to definitively quantify this deviation or speculate on its cause.

Table 4 shows two NCP estimates based on silicate drawdown, reflecting two different ratios for the consumption of silicate to carbon. The traditional estimates of silicate to carbon ratios are 106C:15Si (Brzezinski, 1985), but yield much higher estimates of $\mathrm{NCP}\left(\mathrm{NCP}_{\mathrm{Si}-\mathrm{B}}\right)$ compared to $\mathrm{NCP}_{\mathrm{nDIC}-\mathrm{C}}$ across the shelf except in the southern coastal

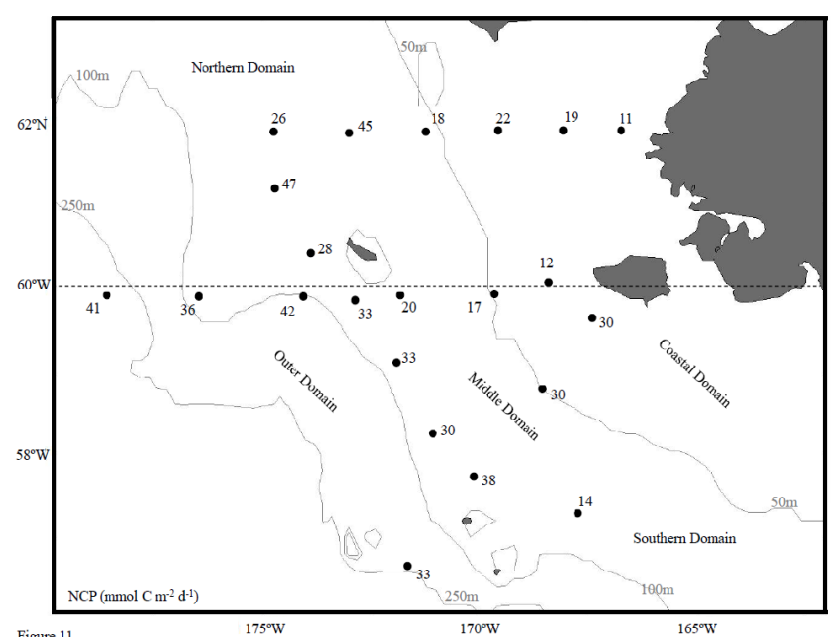

Fig. 11. Net Community Production based on the seasonal consumption of normalized DIC and corrected for the production of calcium carbonate minerals in mmoles $\mathrm{C} \mathrm{m}^{-2} \mathrm{~d}^{-1}$ across the shelf. Values were highest along the central front and lowest along the coast.

domain. An alternative ratio of 106C:40Si was suggested by Aguilar-Islas et al. (2007) for iron-limited systems. NCP estimates based on this ratio $\left(\mathrm{NCP}_{\mathrm{Si}-\mathrm{A}}\right)$ are lower across the entire shelf, but notably low through the southern coastal domain. Comparing these two $\mathrm{NCP}_{S i}$ estimates suggests that iron is not a limiting nutrient in the southern coastal domain, but limits production in varying degrees across the remainder of the shelf.

Other studies in the region show similar values of NCP (e.g., Rho and Whitledge, 2007; Springer et al., 1996; Springer and McRoy, 1993). Springer and McRoy (1993) and Rho and Whitledge (2007) used a combination of estimates from different times during the production season across several years to obtain average annual measurements across the season. Despite high error, average values from Rho and Whitledge were within 10 mmoles $\mathrm{C} \mathrm{m}^{-2} \mathrm{~d}^{-1}$ of the estimates presented here. Springer and McRoy estimated production rates for the Coastal Domain fell within 1.1 mmoles $\mathrm{C} \mathrm{m}^{-2} \mathrm{~d}^{-1}$ of our estimates. The average estimates taken from the "Green Belt" literature review by Springer et al. (1996) also fell within 2.5 mmoles $\mathrm{C} \mathrm{m}^{-2} \mathrm{~d}^{-1}$ of $\mathrm{NCP}_{\mathrm{nDIC}-\mathrm{C}}$.

\subsection{Estimates of early season NCP}

The lack of DIC data on the Bering Sea shelf prior to the spring cruise makes it difficult to determine rates of primary production in the early part of the growing season. However, DIC concentrations were fairly consistent across most of the domains (Fig. 4a-d). nDIC distributions did show locations along the southern end of the shelf where concentrations were slightly lower in some places (Fig. 7a), 
perhaps indicating early season NCP, but these waters were still nutrient-rich (Fig. 8a) and showed no signs of enhanced oxygen production (Fig. 9a). Sea-ice cover was also present at all sampled locations in spring, further reducing the possibility that any significant production had occurred due to limited solar irradiance. It is likely that any productivity that did occur prior to our initial occupation in spring was limited to the water column-ice interface and did not significantly influence our NCP estimates.

\subsection{Assumptions and caveats}

We had to make several assumptions in order to use the seasonal carbon mass balance to estimate NCP. This method does not independently take into account contributions of DIC to the mixed layer through air-sea $\mathrm{CO}_{2}$ gas exchange, vertical diffusion (Bates, 2006) and river discharge. All of these processes do add DIC to the mixed layer, particularly as the season progresses. Additionally, this method overlooks the circulation and movement of water masses. Overall, we estimate that these assumptions may introduce $\sim 15 \%$ combined underestimation in NCP, suggesting that our NCP values are conservative.

Previous studies have indicated that the Bering Sea is a net sink for atmospheric $\mathrm{CO}_{2}$ during ice-free periods (Takahashi et al., 2002, 2009). Bates et al. (2005) determined that in the Chukchi Sea, given a $\mathrm{CO}_{2}$ flux rate from the atmosphere to the surface ocean of $\sim 5-10$ mmoles $\mathrm{CO}_{2} \mathrm{~m}^{-2} \mathrm{~d}^{-1}$ the added contribution of DIC to the mixed layer would be on the order of $\sim 5-10 \mu$ moles kg ${ }^{-1} \mathrm{~d}^{-1}$. Assuming a similar flux into the Bering Sea would add $\sim 4-8$ mmoles $\mathrm{m}^{-2} \mathrm{~d}^{-1}$ to our NCP estimates, an approximately $10-20 \%$ underestimation of NCP. This contribution is likely smaller because the shelf was not $100 \%$ ice-free for the entire period between spring and summer, which would have limited air-sea exchange. DIC concentrations were also not drawn down as much over the Bering Sea shelf as over the Chukchi Sea shelf which would have reduced the air-sea disequilibrium and further reduced the flux of $\mathrm{CO}_{2}$.

Vertical diffusion of $\mathrm{CO}_{2}$ across the interface between the mixed layer and bottom waters would have also contributed only a minor amount $\left(<1-2 \mu\right.$ moles, $\left.\mathrm{kg}^{-1}\right)$ of $\mathrm{CO}_{2}$ to the DIC pool in the upper $30 \mathrm{~m}$. Following the approach of Bates et al. (2005), we estimated vertical diffusivity of $\mathrm{CO}_{2}$ over the Bering Sea shelf as the product of the vertical diffusion coefficient $\mathrm{K}_{v}$, the vertical gradient of inorganic carbon $(\delta \mathrm{DIC} / \delta \mathrm{z})$ below the mixed layer (i.e., vertical gradient in DIC between $30-50 \mathrm{~m}$ ), and the seawater density (Denman and Gargett, 1983). Even though $\mathrm{K}_{v}$, is variable, ranging from $0.2-80 \mathrm{~cm}^{2} \mathrm{~s}^{-1}$ (Denman and Gargett, 1983), and average $\mathrm{K}_{v}$, of $30 \mathrm{~cm}^{2} \mathrm{~s}^{-1}$ (Bates et al., 2005) increased the upper $30 \mathrm{~m}$ DIC pool by $\sim 3.6 \mu$ moles kg ${ }^{-1}$ over a 100 day period. Taking this flux into account would add $\sim 0.7-$ 1.25 mmoles $\mathrm{C} \mathrm{m}^{2} \mathrm{~d}^{-1}$ to our NCP rates estimates. However, the intense stratification that sets up between spring and sum- mer between the surface and bottom layers likely reduced this flux of DIC across the interface.

An overestimation of DIC may occur due to the contribution of DIC and TA contributed by rivers. In order to best estimate this contribution, the volume fraction of river water and its concentration of DIC is typically determined using $\delta \mathrm{O}^{18}$ samples, although these are unfortunately unavailable for this particular dataset. However, the concentration of TA and DIC in river waters discharged over the inner shelf is much lower compared to shelf concentrations, and the dilution effect of these waters is likely much more dramatic than contribution of dissolved contents. While it is not possible to accurately estimate the error that this may introduce to our NCP estimates, we can assume that any error in the normalization processes is likely isolated to the coastal domain, because strong frontal systems block significant cross-shelf advection.

Circulation and movement of water masses over the shelf may have a significant impact on our estimates of NCP. Coachman (1986) calculated the residence time of the outer domain at approximately three months, and speculated that the residence time of waters in the middle and inner domains were much longer due to reduced flow fields. The gap between our seasonal sampling was $\sim 100$ days, which is slightly longer than the residence time reported for the outer shelf, but likely shorter than the residence times for the middle and inner domains. However, the spring distribution of DIC across the shelf was largely uniform so we can assume that inflowing waters had a similar DIC to outflowing waters in the outer domain. It is unlikely that circulation introduces large error to our domain-integrated estimates of NCP.

Although NCP should be conceptually equivalent to new production, as suggested by Williams (1993), this may not be the case in the Bering Sea. Over this time period, some remineralization of organic matter in the upper $30 \mathrm{~m}$ may occur. While most of the particulate organic carbon (POC) is exported in a highly productive sub-Arctic system (e.g,. Mathis et al. 2007), the remineralization of highly labile dissolved organic carbon (DOC) between station occupations (Hansell et al., 1997) can add DIC back into surface layer, decreasing the seasonal drawdown signal. However, any significant contribution of DIC from remineralization directly within the mixed layer seems unlikely given the slow rates of remineralization and the relatively short time between station occupations. It has also been shown in other highly productive polar seas (e.g., Mathis et al., 2006) that only a small fraction of $\mathrm{NCP}(\sim 10 \%)$ is retained in the mixed layer and is available for remineralization on time-scales longer than the difference between measurements. 
Table 5. Annual production of organic carbon based on $\mathrm{NCP}_{\mathrm{nDIC}-\mathrm{C}}$, integrated across the upper $30 \mathrm{~m}$ and area of each domain compared to the annual production of organic carbon reported by Springer et al., 1996. NC indicates the northern coastal domain, SC indicates the southern coastal domain, NM indicates the northern middle domain, SM indicates the southern middle domain, and SO indicates the southern outer domain.

\begin{tabular}{ccccccc}
\hline Domain & $\begin{array}{c}\text { Area } \\
\mathrm{m}^{2}\end{array}$ & $\begin{array}{c}\text { Springer et al., } 1996 \\
\mathrm{TgC} \mathrm{yr}^{-1}\end{array}$ & $\begin{array}{c}\mathrm{NCP}_{\mathrm{DIC}} \\
\mathrm{TgC} \mathrm{yr}^{-1}\end{array}$ & $\begin{array}{c}\mathrm{NCP}_{\mathrm{TN}} \\
\mathrm{TgC} \mathrm{yr}^{-1}\end{array}$ & $\begin{array}{c}\mathrm{NCP}_{\mathrm{PO} 4} \\
\mathrm{Tg} \mathrm{C} \mathrm{yr}^{-1}\end{array}$ & $\begin{array}{c}\mathrm{NCP}_{\mathrm{Si}} \\
\mathrm{Tg} \mathrm{yr}^{-1}\end{array}$ \\
\hline $\mathrm{NC}$ & $2.7 \times 10^{11}$ & & 20.68 & 17.05 & 33.89 & 23.59 \\
$\mathrm{SC}$ & $1.2 \times 10^{11}$ & & 12.47 & 2.35 & 13.82 & 4.55 \\
Total & $3.9 \times 10^{11}$ & 32.0 & 33.1 & 19.4 & 47.7 & 28.1 \\
$\mathrm{NM}$ & $1.7 \times 10^{11}$ & & 27.35 & 21.35 & 27.55 & 22.27 \\
$\mathrm{SM}$ & $1.9 \times 10^{11}$ & & 20.63 & 12.98 & 19.46 & 13.75 \\
Total & $3.6 \times 10^{11}$ & 47.0 & 48.0 & 34.3 & 47.0 & 36.0 \\
$\mathrm{SO}$ & $1.3 \times 10^{11}$ & 23.0 & 20.2 & 23.1 & 20.8 & 18.6 \\
\hline
\end{tabular}

\section{Conclusions}

In the spring and summer of 2008, spatio-temporal variability of inorganic carbon and NCP were measured for the southeastern Bering Sea Shelf region. Hydrographic and biogeochemical characteristics divided this shelf into six distinct regimes. Bottom water temperature and density split the shelf into northern and southern regimes at approximately $60^{\circ} \mathrm{N}$. Frontal systems approximately overlying the $50 \mathrm{~m}$ and $100 \mathrm{~m}$ isobaths also divided the shelf into three zones: the Coastal Domain (0 m-50 m water depth); the Middle Domain (50 m-100 m water depth) and the Outer Domain (100 m$180 \mathrm{~m}$ water depth).

Biogeochemical characteristics were unique in each zone and dictated the character of productivity in each domain. Macronutrient concentrations (i.e., nitrate) were higher nearer the basin, while micronutrient (i.e., iron) concentrations were higher nearer to the coast. As expected, the intersection of these inverse gradients at the Central Front produced the highest rates of NCP in the region $\left(\sim 37\right.$ mmoles $\left.\mathrm{C} \mathrm{m}^{-2} \mathrm{~d}^{-1}\right)$. The limited availability of macronutrients in the inner domain limited NCP to $\sim 17.5 \pm 4.0$ mmoles $\mathrm{C} \mathrm{m}^{-2} \mathrm{~d}^{-1}$ in the northern zone, while an active regeneration loop and sufficient supply of iron likely bolstered inner domain productivity to $\sim 23.7 \pm 6.5$ mmoles $\mathrm{C} \mathrm{m}^{-2} \mathrm{~d}^{-1}$ in the southern zone. Outer Domain NCP rates $\left(\sim 35.5 \pm 6.0\right.$ mmoles $\left.\mathrm{C} \mathrm{m}^{-2} \mathrm{~d}^{-1}\right)$ were very similar to Middle Domain NCP rates $\left(\sim 36.7 \pm 0.7\right.$ mmoles $\mathrm{C} \mathrm{m}^{-2} \mathrm{~d}^{-1}$ in the northern zone and $\sim 24.8 \pm 10.0$ mmoles $\mathrm{C} \mathrm{m}^{-2} \mathrm{~d}^{-1}$ in the southern zone), although increased utilization of nitrate may indicate outer domain NCP rates are high, due to the excessive formation of TA.

By integrating the seasonal consumption of normalized DIC over the upper $30 \mathrm{~m}$ of the water column and the area of each domain and correcting for the formation of calcium carbonate minerals (Table 5), we estimated a total produc- tion of organic carbon over the entire shelf $\left(\sim 8.8 \times 10^{11} \mathrm{~m}^{2}\right)$ at $\sim 97 \pm 29.9 \mathrm{Tg} \mathrm{Cyr}^{-1}\left(1 \mathrm{Tg}=10^{12} \mathrm{~g}\right)$ which is comparable to estimates reported by Springer et al., 1996 of $\sim 102 \mathrm{Tg} \mathrm{Cyr}^{-1}$. Due to the paucity of consistent, comparable productivity data over the shelf it is impossible at this time to quantify whether the system is becoming more or less productive.

In an ecosystem undergoing dynamic change like the southeastern Bering Sea, warming temperatures and earlier retreat of sea ice could expose the surface layer to more wind mixing and subsequent reductions in stratification, thereby decreasing productivity under certain climate scenarios. Hunt et al. (2002) correlates the earlier retreat of sea-ice with higher export to the benthos, thus strengthening the benthic ecosystem (i.e., crab fisheries) at a cost to the pelagic fisheries such as Pollock. However, under another possible scenario, earlier retreat of sea ice could increase the availability of solar radiation, stratify the water column and thus limit production through decreased nutrient fluxes, resulting in a more pelagic-dominated shelf ecosystem.

The impacts of changes in the character of productivity in the Bering Sea would likely be felt downstream in the Chukchi Sea. Waters entering the Arctic Ocean through Bering Strait are modified as they cross the Bering Sea shelf (e.g,. Rudels, 1995). Increased rates of Bering Sea shelf primary production could further increase nutrient depletion and limit productivity in the western Arctic Ocean. Enhanced export production in the Bering Sea could also lower DIC concentrations in the surface waters and thereby increase the $\mathrm{CO}_{2}$ sink in the ocean.

We have shown here that NCP can be a valuable method for assessing primary production over large areas of the Bering Sea. As environmental conditions in the region continue to change, it will be important to monitor the rates of NCP and the fate of the organic matter. Under certain climate scenarios, the vast and highly valuable fisheries of the Bering Sea could be diminished or shifted northward. 
Acknowledgements. The authors thank the officers and crew of the USCGC Healy for their tireless efforts in supporting our work. Without their commitment, none of the science would be possible. We also thank the hydrographic team from NOAA-PMEL for providing the nutrient and dissolved oxygen data discussed here. Finally, we thank our colleagues in the BEST-BSIERP Project, supported by NSF and NPRB. The work presented in this paper was supported by the US Minerals Management Service, Alaska OCS Region and the Coastal Marine Institute at the University of Alaska Fairbanks under Agreement M08AC12645. MWL was supported by NSF award ARC-0732359, and this is BIOS Contribution No. 2001. This is NPRB Publication \# 244 and BEST-BSIERP Publication \# 5.

Edited by: G. Herndl

\section{References}

Aguilar-Islas, A. M., Hurst, M. P., Buck, K. N., Sohst, B., Smith, G. J., Lohan, M. C., and Bruland, K. W.: Micro- and macronutrients in the southeastern Bering Sea: Insight into iron-replete and irondepleted regimes, Prog. Oceanogr., 73, 99-126, 2007.

Andersson, A. J. and Mackenzie, F. T.: Shallow-water oceans: a source or sink for atmospheric $\mathrm{CO}_{2}$ ?, Front Ecol. Environ, 2(7), 348-353, 2004.

Azova, N. V.: Primary productivity of the Pribilof-Bristol area of the Bering Sea, in: Moiseev, P. A., Soviet fisheries investigation in the northeastern Pacific, Part III. Pishchevaya Promyshlennost Publishing, Moscow, VNIRO Proceedings 53 and TINRO Proceedings, 52, 149-154, (in Russian), 1964.

Banse, K. and English, D. C.: Comparing phytoplankton seasonality in the eastern and western subarctic Pacific and the western Bering Sea, Prog. Oceanogr., 43, 235-288, 1999.

Bates, N. R.: Interannual variability of oceanic $\mathrm{CO}_{2}$ and biogeochemical properties in the western North Atlantic subtropical gyre. Deep-Sea Res. Pt. II 48(8-9), 1507-1528, doi:10.1016/S0967-0645(00)00151-X, 2001.

Bates, N. R.: Air-sea $\mathrm{CO}_{2}$ fluxes and the continental shelf pump of carbon in the Chukchi Sea adjacent to the Arctic Ocean, J. Geophys. Res.,111, C10013, doi:10.1029/2005JC003083, 2006.

Bates, N. R. and Mathis, J. T.: The Arctic Ocean marine carbon cycle: evaluation of air-sea $\mathrm{CO}_{2}$ exchanges, ocean acidification impacts and potential feedbacks, Biogeosciences, 6, 2433-2459, doi:10.5194/bg-6-2433-2009, 2009.

Bates, N. R., Hansell, D. A., Carlson, C. A., and Gordon, L. I.: Distribution of $\mathrm{CO}_{2}$ species, estimates of net community production, and air-sea $\mathrm{CO}_{2}$ exchange in the Ross Sea polynya, J. Geophys. Res.-Ocean, 103(C2), 2883-2896, 1998a.

Bates, N. R., Takahashi, T., Chipman, D. W., and Knap, A. H.: Variability of $p \mathrm{CO}_{2}$ on diel to seasonal timescales in the Sargasso Sea, J. Geophys. Res. 103(15), 567-1558, 1998 b.

Bates, N. R., Best M. H. P., and Hansell, D. A.: Spatio-temporal distribution of dissolved inorganic carbon and net community production in the Chukchi and Beaufort Seas, Deep-Sea Res. Pt. II, 52(22-24), 3324-3343, doi:10.1016/j.dsr2.2005.10.003, 2005.

Bates, N. R., Pequignet, A. C., and Sabine, C. L.: Ocean carbon cycling in the Indian Ocean: II. Estimates of net com- munity production, Global Biogeochem. Cy., 20(3), GB3021, doi:10.1029/2005GB002492, 2006.

Bates, N. R., Pequignet, A. C., and Sabine, C. L.: Ocean carbon cycling in the Indian Ocean: 1. Spatiotemporal variability of inorganic carbon and air-sea $\mathrm{CO}_{2}$ gas exchange, Global Biogeochem. Cy., 20(3), GB3020, doi:10.1029/2005GB002491, 2006.

Bates, N. R., Mathis, J. T., and Cooper, L.: Ocean acidification and biologically induced seasonality of carbonate mineral saturation states in the Western Arctic Ocean, J. Geophys. Res., 114, C11007, doi:10.1029/2008JC004862, 2009.

Bond, N. A., Overland, J. E., Spillane M., and Stabeno P.: Recent shifts in the state of the North Pacific, Geophys. Res. Lett., 30(23), 2183, doi:10.1029/2003GL018597, 2003.

Bond, N. A. and Overland, J. E.: The importance of episodic weather events to the ecosystem of the Bering Sea shelf, Fish. Oceanogr., 14, 97-111, 2005.

Bryan, K. and Spelman, M. J.: The Ocean's Response to a $\mathrm{CO}_{2-}$ Induced Warming, J. Geophys. Res., 90(C6), 11679-11688, 1985.

Brzezinski, M. A.: The Si:C:N ratio of marine diatoms: Interspecific variability and the effect of some environmental variables, J. Phycol., 21, 347-357, 1985.

Chipman, D. W., Marra, J., and Takahashi, T.: Primary production at $47^{\circ} \mathrm{N}$ and $20^{\circ} \mathrm{W}$ in the North Atlantic Ocean: a comparison between the ${ }^{14} \mathrm{C}$ incubation method and the mixed layer carbon budget, Deep-Sea Res., 40, 151-169, 1993.

Coachman, L. K. and Charnell, R. L.: On later water mass interaction - a case study, Bristol Bay, Alaska, J. Phys. Oceanogr., 9, 278-297, 1979.

Coachman, L. K.: Circulation, water masses, and fluxes on the southeastern Bering Sea shelf, Cont. Shelf Res., 5, 23-108, 1986.

Coachman, L. K. and Charnell, R. L.: On lateral water mass interaction-a case study, Bristol Bay, Alaska, J. Phys. Oceanogr., 9(2), 278-297, 1979.

Codispoti, L. A., Friederich, G. E., Iverson, R. L. and Hood, D.W.: Temporal changes in the inorganic carbon system of the southeastern Bering Sea during spring 1980, Nature, 296, 242-245, 1982.

Codispoti, L. A., Friederich, G. E., and Hood, D. W.: Variability in the inorganic carbon system over the southeastern Bering Sea shelf during spring 1980 and spring - summer 1981, Cont. Shelf Res., 5(1-2), 133-160, 1986.

Coyle, K. O., Pinchuk, A. I., Eisner, L. B., and Napp, J. M.: Zooplankton species composition, abundance, and biomass on the eastern Bering Sea shelf during summer: The potential role of water-column stability and nutrients in structuring the zooplankton community, Deep Sea Res. Pt. II, 55, 1775-1791, 2008.

Denman, K. L. and Gargett A. E.: Time and space scales of vertical mixing and advection of phytoplankton in the upper ocean, Limnol. Oceanogr., 28(5), 801-815, 1983.

Dickson, A. G., Sabine, C. L, and Christian, J. R.: Guide to Best Practices for Ocean $\mathrm{CO}_{2}$ measurements, PICES Special Publication, 3, 191 pp., 2007.

Eppley, R. W. and Peterson, B. J.: Particulate organic matter flux and planktonic new production in the deep ocean, Nature, 282, 677-680, 1979.

Francis, R. C., Hare, S. R., Hollowed, A. B., and Wooster, W. S.: Effects of interdecadal climate variability y on the oceanic ecosystems of the NE Pacific, Fish. Oceanogr., 7, 1-21, 1998. 
Franks, P. J. S.: Sink or swim: accumulation of biomass at fronts. Mar. Ecol. Prog.-Ser., 82, 1-12, 1992.

Fujishima, Y., Ueda, K., Maruo, M., Nakayama, E., Tokutome, C., Hasegawa, H., Matsui, M., and Sohrin, Y.: Distribution of trace bioelements in the subarctic North Pacific Ocean and the Bering Sea, J. Oceanogr., 57, 261-273, 2001.

Fung, I. Y., Meyn, S. K., Tegen, I., Doney, S. C., John, J. G., and Bishop, J. K. B.: Iron supply and demand in the upper ocean, Global Biogeochem. Cy., 14, 281-291, 2000.

Gordon, L. I., Jennings Jr., J. C., Ross, A. A., Krest, J. M.: A suggested protocol for continuous automated analysis of seawater nutrients (phosphate, nitrate, nitrite and silicic acid) in the WOCE Hydrographic program and the Joint Global Ocean Fluxes Study.WOCE Operations Manual, vol. 3: The Observational Programme, Section 3.2: WOCE Hydrographic Programme, Part 3.1.3: WHP Operations and Methods.WHP Office ReportWHPO 91-1; WOCE Report No. 68/91. November, 1994, Revision 1, Woods Hole, MA, USA, 52 loose-leaf pages, 1993.

Graham, H. W. and Edwards, R. L.: The World biomass of marine fishes. In Heen, E. (ed.), Primary Production in the Sea, Plenum Press, New Jersey, pp 433-460, 1962.

Grebmeier, J. M., Overland, J. E., Moore, S. E., Farley, E. V., Carmack, E. C., Cooper, L. W., Frey, K. E., Helle, J. H., McLaughlin, F. A., and McNutt, S. L.: A major ecosystem shift in the northern Bering Sea. Science, 311, 1461-1464, 2006.

Grebmeier, J. M. and McRoy, C. P.: Pelagic-Benthic coupling on the shelf of the northern Bering and Chukchi Seas III. Benthic food supply and carbon cycling, Mar. Ecol. Prog.-Ser., 53, 7991, 1989.

Hansell, D. A., Whitledge, T. E., and Goering, J. J.: Patterns of nitrate utilization and new production over the Bering-Chukchi shelf, Cont. Shelf Res., 13, 601-628, 1993.

Hansell, D. A., Bates, N. R. and Carlson, C. A.: Predominantly vertical losses of carbon from the surface layer of the Equatorial Pacific Ocean, Nature, 386, 59-61, 1997.

Hattori, A. and Goering, J. J.: Nutrient distributions and dynamics in the Eastern Bering Sea, in: Hood, D.W. and Calder, J. A., The eastern Bering Sea Shelf: Oceanogrphy and resources, Oceanography, 3(3), 130 pp., 1981.

Hollowed, A. B., Hare, S. R., and Wooster, W. S.: Pacific-Basin climate variability and patterns of northeast Pacific marine fish production. Prog. Oceanogr., 49, 257-282, 2001.

Hunt Jr., G. L., Stabeno, P. J., Walters, G., Sinclair, E., Brodeu, R. D., Napp, J. M. and Bond, N. A.: Climate change and control of the southeastern Bering Sea pelagic ecosystem, Deep-Sea Res. Pt. II, 49, doi:S0967-0645(02)00321-1, 2002.

Hunt, G. L., and Stabeno P. J.: Climate change and the control of energy flow in the southeastern Bering Sea, Prog. Oceanogr., 55, 5-22, 2002.

Hutchins, D. A. and Bruland, K. W.: Iron-limited diatom growth and Si:N uptake ratios in a coastal upwelling regime. Nature, 393, 591-564, 1998.

Ivanenkov, V. N.: Primary production in the Bering Sea, Trans. Inst. Oceanol. Acad. Sci. USSR, Moscow, 51, 36-56, (in Russian), 1961.

Kachel, N. B., Hunt, G., Salo, S. A., Schumacher, J. D., Stabeno, P. J., and Whitledge, T. E.: Characteristics of the Inner Front of the Southeastern Bering Sea, Deep Sea Res. Pt. II, 49, 5889-5909, 2002.
Karl, D. M., Tilbrook, B. D., and Tien, G.: Seasonal coupling of organic matter production and particle flux in the western Bransfield Strait, Antarctica, Deep-Sea Res., 38, 1097-1126, 1991.

Khen, G. V.: Oceanographic conditions and Bering Sea biological productivity, in: Proceedings of the International Symposium on the Biology and management of Walleye Pollock. Ancorage, AK: Alaska Sea Grant Rep., 89-1:79-94, 1988.

Kinder, T. H. and Coachman, L. K.: The front overlying the continental slope in the eastern Bering Sea, J. Geophys. Res., 83, 4551-4559, 1978.

Koike, I., Ogawa, H., Nagata, T., Fukuda, R., and Fukuda, H.: Silicate to nitrate ratio of the upper sub-arctic pacific and the bering sea basin in summer: its implication for phytoplankton dynamics, J. Oceanogr., 57, 253-260, 2001.

Koblentz-Mishke, O. I., Volkovinsky, V. V., and Kabanova, I. G.: Plankton primary production in the world ocean, Scientific Exploration of the South Pacific, 183-193, 1970.

Kruse, G. H.: Salmon run failures in 1997-1998: A link to anomalous ocean conditions?, Alaska Fishery Research Bulletin, 5(1), 55-63, 1998.

Lee, K.: Global net community production estimated from the annual cycle of surface water total dissolved inorganic carbon, Limnol. Oceanogr., 46(6), 1287-1297, 2001.

Lee, K., Karl, D. M., Wanninkhof, R., and Zhang, J. Z.: Global estimates of net carbon production in the nitrate-depleted tropical and subtropical oceans, Geophys. Res. Lett., 29(19), 1907, doi:10.1029/2001GL014198, 2002.

Lovvorn, J. R., Cooper, L. W., Brooks, M. L., de Ruyck, C. C., Bump, J. K., and Grebmeier, J. M.: Organic matter pathways to zooplankton and benthos under pack ice in late winter and open water in late summer in the north-central Bering Sea, Mar. Ecol. Prog.-Ser., 291, 135-150, 2005.

Mackas, D. L., Denman, K .L., and Abbott, M. K.: Plankton patchiness: biology in the physical vernacular, Bull. Mar. Sci., 37, 652-674, 1985.

Macklin, S. A., Hunt Jr. G. L., and Overland, J. E.: Collaborative research on the pelagic ecosystem of the southeastern Bering Sea shelf, Deep-Sea Res. Pt. II, 49(26), 5813-5819, 2002.

Maeda, T.: Relationship between annual fluctuation of oceanographic conditions and abundance of year classes of the yellowfin sole in the eastern Bering Sea. In Fisheries Biological Production in the Subarctic Pacific Region. Hakodate, Japan: Hokkaido University, Special Volume, pp. 259-268, 1977.

Mathis, J. T., Bates, N. R., Hansell, D. A., and Babila, T.: Net community production in the northeastern Chukchi Sea, Deep-Sea Res. Pt. II, 56(17), 1213-1222, doi:10.1016/j.dsr2.2008.10.017, 2009.

Mathis, J. T., Hansell, D. A., Kadko, D., Bates, N. R., and Cooper, L. W.: Determining net dissolved organic carbon production in the hydrographically complex western Arctic Ocean, Limnol. Oceanogr., 52(5), 1789-1799, 2007.

McRoy, C. P. and Goering, J. J.: Annual budget of primary production of the Bering Sea, Marine Science Communications, 2, 255-267, 1976.

McRoy, C., Whitledge, T. E., Springer, A. M., Simpson, E. P.: The nitrate front in the Bering Sea: is this an iron curtain? Oral presentation abstract, http://www.aslo.org/meetings/ aslomeetings.html, 2001.

Mizobata, K. and Saitoh, S.: Variability of Bering Sea eddies and 
primary productivity along the shelf edge during 1998-2000 using satellite multisensor remote sensing, J. Marine Syst., 50, 101-111, 2004.

Mizobata, K., Saitoh, S. I., Shiomoto, A., Miyamura, T., Shiga, N., Imai, K., Toratani, M., Kajiwara, Y., and Sasaoka, K.: Bering Sea cyclonic and anticyclonic eddies observed during summer 2000 and 2001 Prog. Oceanogr., 55, 65-75, 2002.

Moore, J. K., Doney, S. C., Glover, D. M., and Fung I. Y.: Iron cycling and nutrient-limitation patterns in surface waters of the World Ocean, Deep Sea Res. Pt. II, 49(1-3), 463-507, 2001.

Motoda, S. and Minoda, T.: Plankton in the Bering Sea, edited by: Hood, D. and Kelley, E., Oceanography of the Bering Sea, University of Alaska, Fairbanks, pp 207-241, 1974.

Napp, J. M., and Hunt Jr., G. L.: Anomalous conditions in the southeastern Bering Sea, 1997: linkages among climate, weather, ocean, and biology, Fish. Oceanogr., 10(1), 61-68, 2001.

Niebauer, H. J., Alexander, V., and Henrichs, S.: Physical and biological oceanographic interaction in the spring bloom at the Bering Sea marginal ice-edge zone, J. Geophys. Res., 95, 2222922241, 1990.

Niebauer, H. J., Alexander V., and Henrichs S. M.: A time-series study of the spring bloom at the Bering Sea ice edge. I: Physical processes, chlorophyll and nutrient chemistry, Cont. Shelf Res., 15, 1859-1878, 1995.

NRC (National Research Council), The Bering Sea Ecosystem, National Academy Press, 305 pp., 1996.

Ohtani, K. and Azumaya, T.: Influence of interannual changes in ocean conditions on the abundance of walleye pollock (Theragra chalcogramma) in the eastern Bering Sea. Pp. 87-95 in North Pacific Workshop on Stock Assessment and management of Invertebrates, edited by: Beamish, R. J., Can Spec. Publ. Fish. Aquat. Sci., 92, 87-95, 2002.

Okkonen, S. R., Schmidt, G. M., Cokelet, E. D., and Stabeno, P. J.: Satellite and hydrographic observations of the Bering Sea "Green Belt", Deep-Sea Res. Pt. II, 51, 1033-1051, 2004.

Overland, J. E. and Stabeno, P.: Is the climate of the Bering Sea warming and affecting the ecosystem? EOS Trans., American Geophysical Union, 85, 309-316, 2004.

Parsons, T. R.: The impact of industrial fisheries on the trophic structure of marine ecosystems. In G.A. Polis and K.O. Winemiller (Eds.), Food webs: Integration of patterns and dynamics (pp. 352-357), New York, Chapman and Hall, 1996.

Pease, C. H.: Eastern Bering Sea ice processes, Mon. Weather Rev., 108, 2015-2023, 1980.

Rho, T., Whitledge, T. E., and Goering, J. J.: Interannual variations of nutrients and primary production over the southeastern Bering Sea shelf during the spring of 1997, 1998 and 1999, Oceanology, 45, 376-390, 2005.

Rho, T. and Whiledge, T. E.: Characteristics of seasonal and spatial variations of primary production over the southeastern Bering Sea shelf, Cont. Shelf Res., 27, 2556-2569, 2007.

Roots, E. F.: Climate Change: High Latitude Regions, Climatic Change, 15, 223-253, 1989.

Rudels, B.: The thermohaline circulation of the Arctic Ocean and the Greenland Sea, Philos. Trans. R. Soc. Lond., A. 352, 287299, 1995.

Saino, T., Miyata, K., and Haqttori, A.: Primary productivity in the Bering and Chukchi Seas and in the norther North Pacific in summer 1978, Bull. Plankton Soc. Jpn., 26, 96-103, 1979.
Saitoh, S., Iida, T., and Sasaoka, K.: A description of temporal and spatial satellite multi-sensor remote sensing. Prog. Oceanogr., 55(1-2), 131-146, 2002.

Sambrotto, R. N., and Goering, J. J.: Interannual variability of phytoplankton and zooplankton production on the southeast Bering Sea shelf, edited by: Wooster, W. S., From Year-to-Year: Interannual Variability of the Environment and Fisheries of the Gulf of Alaska and the Eastern Bering Sea, Washington State Sea Grant, Seattle, WA, pp. 161-177, 1983.

Sambrotto, R. N., Mordy, C., Zeeman, S. I., Stabeno, P. J., and Macklin, S. A.: Physical forcing and nutrient conditions associated with patterns of $\mathrm{Chl} a$ and phytoplankton productivity in the southeastern Bering Sea during summer, Deep Sea Res. Pt.II, 55, 1745-1760, 2008.

Sambrotto, R. N., Niebauer, H. J., Goering, J. J., and Iverson, R. L.: Relationships among vertical mixing, nitrate uptake, and phytoplankton growth during the spring bloom in the southeast Bering Sea middle shelf, Cont. Shelf Res., 5, 161-198, 1986.

Sambrotto, R. N., Savidge, G., Robinson, C., Boyd, P., Takahashi, T., Karl, D. M., Langdon, C., Chipman, D., Marra, J., and Codispoti, L.: Elevated consumption of carbon relative to nitrogen in the surface ocean, Nature, 363, 248-250, 1993.

Sapozhnikov, V. V. and Naletova, I. A.: Studies of the biohydrochemical structure of the euphotic layer and primary production in the Bering Sea, Oceanology, 35(2), 189-196, 1995.

Scheffer, M., Carpenter, S., Foley, J. A., Folke, C., and Walker, B.: Catastrophic shifts in ecosystems, Nature, 413(6856), 591-96, 2001.

Schumacher, J. D. and Reed, R. K.: Characteristics of currents near the continental slope of the eastern Bering Sea, J. Geophys. Res., 97, 9423-9433, 1992.

Schumacher, J. D., Bond, N. A., Brouder, R. D., Livingston, P. A., Napp, J. M. and Stabeno, P. J.: Climate changes in the southeastern Bering Sea and some consequences for biota. In Large marine ecosystems of the world: Trends in exploitation, Protection and Research, edited by: Hemple, G., Sherman, K., Elsevier, Amsterdam, 2002.

Schumacher, J. D. and Stabeno, P. J.: The continental Shelf of the Bering Sea, in: The Sea: Vol. 11 - The Global Coastal Ocean: Regional Studies and Synthesis, John Wiley and Sons, Inc., New York, NY, 789-822, 1998.

Schumacher, J. D. and Stabeno, P. J.: Ubiquitous eddies of the eastern Bering Sea and their coincidence with concentrations of larval pollock, Fish. Oceanogr., 3, 182-190, 1994.

Schumacher, J. D. and Alexander, V.: Variability and role of the physical environment in the Bering Sea ecosystem, in: Dynamics of the Bering Sea, edited by: Loughlin, T.R. and Ohtani, K., University of Alaska Sea Grant, Fairbanks, Alaska, AK-SG-9903, pp. 147-160, 1999.

Serreze, M. C. and Francis, J. A.: The Arctic amplification debate, Climate Change, 76, 241-64, 2006.

Simpson, E. and McRoy, C.: Model evidence of a Bering Sea iron curtain. Oral presentation abstract, http://www.aslo.org/ meetings/aslomeetings.html, 1999.

Sorokin, Yu. I.: Data on primary production in the Bering Sea and adjacent Norther Pacific, J. Plankton Res., 21(4), 615-636, 1999.

Sorokin, Yu. I. and Mikheev, V. N.: Characteristics of the Peruvian upwelling ecosystem, Hydrobiologia, 62, 165-189, 1979.

Sorokin, Yu. I.: On the methodology of primary production mea- 
surements in the sea with the use of 14C. Trans., USSR, Hydrobiol. Soc., Moscow, 10, 235-254, 1960.

Springer, A. M. and McRoy, C. P.: The paradox of pelagic food webs in the northern Bering Sea-III. Patterns of primary production, Cont. Shelf Res., 13, 575-599, 1993.

Springer, A. M., McRoy, C. P., and Flint, M. V.: The Bering Sea Green Belt: shelf-edge processes and ecosystem production, Fish. Oceanogr., 5(3-4), 205-223, 1996.

Springer, A. M.: Is it all climate change? Why marine bird and mammal populations fluctuate in the North Pacific, in: Biotic impacts of extratropical climate change in the Pacific. 'Aha Huliko'a Proceedings Hawaiian Winter Workshop, University of Hawaii, pp 109-119, 1998.

Stabeno, P. J., Kachel, N. B., Sullivan, P., and Whitledge, T. E.: Variability along the $70 \mathrm{~m}$ isobath of the southeastern Bering Sea, Deep Sea Res. Pt. II, 49, 5931-5943, 2002.

Stabeno, P. J. and van Meurs, P.: Evidence of episodic on-shelf flow in the southeastern Bering Sea, J. Geophys. Res., 104(29), 715729, 1999.

Stabeno, P. J., and Hunt Jr., G. L.: Overview of the inner front and southeast Bering Sea carrying capacity programs, Deep-Sea Res. Pt. II, 49(26), 6157-6168, 2002.

Stabeno, P. J., Hunt Jr., G. L., Napp, J. M., and Schumacher, J. D.: Physical forcing of ecosystem dynamics on the Bering Sea shelf, in: Robinson, A.R. and Brink, K., The Sea vol. 14B, The Global Coastal Ocean: Interdisciplinary Regional Studies and Syntheses, Harvard University Press, 2006.

Stabeno, P. J., Schumacher, J. D., and Ohtani, K.: The physical oceanography of the Bering Sea, in: Dynamics of the Bering Sea: A Summary of Physical, Chemical, and Biological Characteristics, and a Synopsis of Research on the Bering Sea, edited by: Loughlin, T. R. and Ohtani, K., North Pacific Marine Science Organization (PICES), Univ. of Alaska Sea Grant, AK-SG-9903, 1-28, 1999.

Stockwell, D. A., Whitledge, T. E., Zeeman, S. I., Coyle, K. O., Napp, J. M., Brodeur, R. D., Pinchuk, A. I., and Hunt Jr. G. L.: Anomalous conditions in the south-eastern Bering Sea, 1997: nutrients, phytoplankton and zooplankton, Fish. Oceanogr., 10, 99-116, 2001

Suzuki, K., Liu, H., Saino, T., Obata, H., Takano, M., Okamura, K., Sohrin, Y., and Fujishima, Y.: East-west gradients in the photosynthetic potential of phytoplankton and iron concentration in the subarctic Pacific Ocean during early summer, Limnol. Oceanogr., 46, 1581-1594, 2002.

Takahashi, T., Sutherland, S. C., Sweeney, C., Poisson, A., Metzl, N., Tilbrook, B., Bates, N., Wanninkhof, R., Feely, R. A., Sabine, C., Olafsson, J., and Nojiri, Y.: Global sea - air $\mathrm{CO}_{2}$ flux based on climatological surface ocean $p \mathrm{CO}_{2}$, and seasonal biological and temperature effects. Deep-Sea Res. Pt. II, 49(9-10), 16011622, doi:10.1016/S0967-0645(02)00003-6, 2002.

Takahashi, T., Sutherland, S. C., Wanninkhof, R., Sweeney, C., Feely, R. A., Chipman, D. W., Hales, B., Friederich, G., Chavez, F., Watson, A., Bakker, D. C. E., Schuster, U., Metzl, N., Yoshikawa-Inoue, H., Ishii, M., Midorikawa, Nojiri, Y., Kortzinger, A., Steinhoff, T., Hoppema, M., Olafsson, J., Arnarson, T. S., Tilbrook, B., Johannessen, T., Olsen, A., Bellerby, R., Wong, C. S., Delille, B., Bates, N. R., and de Baar, H. J. W.: Climatological mean and decadal change in surface ocean $p \mathrm{CO}_{2}$, and net sea-air $\mathrm{CO}_{2}$ flux over the global oceans, Deep-Sea Res.
Pt. II, 56(8-10), 554-577, doi:10.1016/j.dsr2.2008.12.009, 2009.

Takata, H., Kuma, K., Iwade, S., and Isoda, Y.: Comparative vertical distributions of iron in the Japan Sea, the Bering Sea, and the western North Pacific Ocean, J. Geophys. Res., 110, CO7004, doi: 10.1029/2004JC002783, 2005.

Tsiban, A. V. and Korsak, M. N.: Primary and microbial production in the Bering Sea. Biol. Sea (Valdivostok), 6, 15-21, (in Russian), 1987.

Turner, J., Overland, J. E., and Walsh, J. E.: An Arctic and Antarctic perspective on recent climate change, Int. J. Climatol., 27, 277293, 2007.

Varela, D. E. and Harrison, P. J.: Seasonal variability in the nitrogenous nutrition of phytoplankton in the northeastern subarctic $\mathrm{Pa}-$ cific Ocean, Deep-Sea Res. Pt. II, 46, 2505-2538, 1999.

Walsh, J. E. and Johnson, C. M.: An analysis of Arctic sea ice fluctuations, 1953-1977, J. Phys. Oceanogr., 9, 580-591, 1979.

Weiss, R. F., Ostlund, H. G., and Craig, H.: Geochemical studies of the Weddell Sea, Deep-Sea Res., 26, 1093-1120, 1979.

Whitledge, T. E., Bidigare, R. E., Zeeman, S. I., Sambrotto, R. N., Rascigno, P. F., Jensen, P. R., Brooks, J. M., Trees, C., and Veidt, D. M.: Biological measurements and related chemical features in Soviet and United States regions of the Bering Sea, Cont. Shelf Res., 8, 1299-1319, 1988.

Whitledge, T. E., Reeburgh, W. S., and Walsh, J. J.: Seasonal inorganic nitrogen distributions and dynamics in the southeastern Bering Sea, Cont. Shelf Res. 5, 109-132, 1986.

Whitledge, T. E. and Luchin V. A.: Summary of chemical distributions and dynamics in the Bering Sea, edited by: Loughlin, T. R. and Ohtani, K., Dynamics of the Bering Sea, University of Alaska Sea Grant, Fairbanks, AK, pp. 217-249, 1999.

Williams, P. J.: On the definition of plankton production terms, edited by: Li, W. K. W. and Maestrini, S. Y., Measurements of Primary Production from the Molecular to the Global Scale, ICES Mar. Sci. Symp., 197, 9-19, 1993.

Wong, C. S., Waser, N. A. D., Nojiri, Y., Whitney, F. A., Page, J. S. and Zeng, J.: Seasonal cycles of nutrients and dissolved inorganic carbon at high and mid latitudes in the North Pacific Ocean during the Skaugran cruises: determination of new production and nutrient uptake ratios, Deep-Sea Res. Pt. II, 49, 5317-5338, 2002.

Wyllie-Escheveria, T. and Wooster, W. S.: Year-to-year variations in Bering Sea ice cover and some consequences for fish distributions, Fisheries Oceangraphy, 7(2), 159-170, 1998.

Wyllie-Escheveria, T.: Seasonal sea ice, the cold pool and gadid distribution on the Bering Sea shelf. Ph.D. dissertation, $281 \mathrm{pp}$, Univ. Of Alaska, Fairbanks, 1995.

Yager, P. L., Wallace, D. W. R., Johnson, K. M., Smith, W. O., Minnett, P. J., and Deming, J. W.: The Northeast Water Polynya as an atmospheric $\mathrm{CO}_{2}$ sink: A seasonal rectification hypothesis, J. Geophys. Res., 100, 4389-4398, 1995. 